\title{
Synthesis and biological evaluation of radio-iodinated benzimidazoles as SPECT imaging agents for NR2B subtype of NMDA receptor
}

Takeshi Fuchigami ${ }^{\text {a,c }}$, Hiroshi Yamaguchi ${ }^{\text {b }}$, Mikako Ogawa ${ }^{\mathrm{a}}$, Le Biao ${ }^{\mathrm{a}}$, Morio Nakayama $^{\mathrm{c}}$, Mamoru Haratake ${ }^{\mathrm{c}}$, Yasuhiro Magata ${ }^{\mathrm{a}, \mathrm{b}^{*}}$

a Photon Medical Research Center, Hamamatsu University School of Medicine, Hamamatsu 431-3192, Japan

${ }^{\mathrm{b}}$ Molecular Imaging Frontier Research Center, Hamamatsu University School of Medicine, Hamamatsu 431-3192, Japan

${ }^{\mathrm{c}}$ Graduate School of Biomedical Sciences, Nagasaki University, 1-14 Bunkyo-machi, Nagasaki 852-8521, Japan

*corresponding author:

Yasuhiro Magata,

Photon Medical Research Center, Hamamatsu University School of Medicine, Hamamatsu 431-3192, Japan.

Tel.: +81-53-435-2398;

Fax: +81-53-435-2398;

E-mail: magata@hama-med.ac.jp 


\begin{abstract}
In this study, the benzimidazole derivatives were synthesized and evaluated as imaging agents for the NR2B subype of NMDA receptor. Among these ligands, 2-\{[4-(4-Iodobenzyl) piperidin-1-yl]methyl $\}$ benzimidazol-5-ol (8) and $N$-\{2-[4-(4Iodobenzyl)-piperidin- 1-ylmethyl]benzoimidazol -5-yl\}-methanesulfonamide (9) exhibited high affinity for the NR2B subunit (Ki values; $7.28 \mathrm{nM}$ for 8 and $5.75 \mathrm{nM}$ for 9). In vitro autoradiography experiments demonstrated high accumulation in the forebrain regions but low in the cerebellum for both $\left[{ }^{125} \mathrm{I}\right] \mathbf{8}$ and $\left[{ }^{125} \mathrm{I}\right] 9$. These regional distributions of the radioligands correlated with the expression of the NR2B subunit. The in vitro binding of these ligands was inhibited by NR2B antagonist but not by other site ligands, which suggested the high selectivity of $\left[{ }^{125} \mathrm{I}\right] \mathbf{8}$ and $\left[{ }^{125} \mathrm{I}\right] \mathbf{9}$ for the NR2B subunit. In mice, the regional brain uptakes of $\left[{ }^{125} \mathrm{I}\right] \mathbf{8}$ and $\left[{ }^{125} \mathrm{I}\right] \mathbf{9}$ at $5-180$ minutes after administration were $0.42-0.56$ and $0.44-0.67 \%$ dose/g, respectively. The brain to blood ratio of $\left[{ }^{125} \mathrm{I}\right] \mathbf{8}$ at 180 minutes was reduced by $34 \%$ in the presence of non-radioactive ligands and by 59\% in the presence of the NR2B ligand Ro-25,6981. These results indicated that $\left[{ }^{125} \mathrm{I}\right] \mathbf{8}$ could be partially bound to the NR2B subunit in vivo. Although the brain uptake of these benzimidazole derivatives was too low to allow for in vivo SPECT imaging, these compounds might be useful scaffolds for the development of imaging probes specific for the NMDA receptors.
\end{abstract}

\title{
Keywords:
}

NMDA receptor, NR2B subtype, benzimidazole, SPECT 


\section{Introduction}

The $N$-methyl-D-aspartate (NMDA) receptor, a member of the glutamate receptors, plays an important role in the neurotransmission function of the central nervous system (CNS). ${ }^{1}$ Overactivation of the NMDA receptor, however, is thought to cause various disorders, such as ischemia, stroke, Parkinson's Disease, Alzheimer's Disease, Huntington's Disease, and schizophrenia. ${ }^{2-6}$ NMDA receptors are heteromers, which contain an NR1 subunit and one or more types of the different NR2 subunits (NR2A-D). ${ }^{7}$ NR1 subunit has only one gene (8 splice variants) with ubiquitous distribution in the brain. NR2 subunits, on the other hand, exhibit distinct distribution in the brain, which determine the synaptic localization and function of the NMDA receptor. The NR2A subunit is widely distributed throughout the brain; but, the NR2B subunit is confined in the forebrain region, including the cerebral cortex, hippocampus, and olfactory bulb. The NR2C and NR2D are localized in the cerebellum and diencephalus/lower brain stem, respectively. The NR2A and NR2B are known to be the predominant NR2 subunits in the adult forebrain. ${ }^{8}$ It is suggested that NR2A-containing NMDA receptors are involved in prosurvival signaling; thereby, they exert a neuroprotective action against glutamate receptor-dependent apoptotic neuronal injuries. ${ }^{9-11}$ On the other hand, an increasing number of reports have demonstrated the importance of the NR2B subunit in determining the pharmacological and functional properties of the NMDA receptor. The NR2B has been implicated in modulating functions, such as learning, memory processing, and feeding behaviors, as well as being involved in a number of human disorders. ${ }^{12}$ It is suggested that activation of the NR2B-containing NMDA receptor initiates apoptotic signaling cascades and promotes neuronal death. ${ }^{9-11}$ Recent progress in molecular biology revealed the in vitro function of the NR2B-containing NMDA receptor considerably. However, its function in the living brain is not well understood due to the lack of visualizing method in vivo. positron emission tomography (PET) and single photon emission computed tomography (SPECT) are the most efficient imaging methods for in vivo measurement of neurotransmitter receptors and enzymes in the brain. Our study, as well as other studies, have developed several radioligands for the NR2B subunit of the NMDA receptor (Fig. 1). These ligands showed similar accumulation pattern with the localization of expression of the NR2B subunit only under in vitro condition but not in vivo. ${ }^{13-19}$ Among these ligands, only $\left[{ }^{11} \mathrm{C}\right]$ EMD-95885 showed significant reduction of the in vivo brain uptake by treatment with the NR2B ligand. ${ }^{16}$ Although the inhibition pattern was inconsistent with NR2B expression, this chemical structure might be a 
useful lead for the development of potential imaging probes. Recently, a new series of benzimidazole derivatives $\mathbf{1}$ and $\mathbf{2}$ are developed as novel NR2B antagonists (Fig. 2), ${ }^{20}$ which have similar chemical structures with EMD-95885. For example, compound 1a showed excellent affinity for the NR2B subunit $(K \mathrm{i}=1.5 \mathrm{nM})$. Introduction of a hydrophobic substituent into the $\mathrm{R}_{2}$-position of benzimidazoles, such as compound $\mathbf{1}$, maintained receptor affinity. ${ }^{20-22}$ On the bases, we designed new SPECT imaging agents, which introduced ${ }^{125} \mathrm{I}$ atom into the $\mathrm{R}_{2}$-position of benzimidazoles. In this study, $\left[{ }^{125} \mathrm{I}\right]$ labeled benzimidazole derivatives were synthesized and the in vitro binding properties and in vivo brain uptake characteristics in rodents were examined. It is reported that ${ }^{11} \mathrm{C}$ labeled 4-acetoxy derivative of L-703,717, which is a PET ligand for glycine site of NMDA receptor, can be a substrate of $\mathrm{P}-\mathrm{gp}^{23}$. However it is not clear if the NR2B ligands are substrates of P-gp. Some of NR2B ligands such as ifenprodil and benzidazoles in this series have acidic phenol group. It has been shown that organic anion transporter is responsible for the elimination of several acidic drugs from the brain across the $\mathrm{BBB}^{24}$. Therefore the effect of P-gp and OAT on the in vivo uptake of $\left.{ }^{125} \mathrm{I}\right]$ benzimidazoles were also investigated.

\section{Results and discussion}

\subsection{Chemistry}

Based on the previous structure-activity relationship studies, ${ }^{20-22}$ the SPECT imaging agent candidates $\mathbf{8}, \mathbf{9}$, and $\mathbf{1 3}$ were designed, in which an iodine atom was introduced into the 4'-position ( $\mathrm{R}_{2}$-position) of benzyl- or phenoxy-piperidine group of benzimidazoles. Lead compound 1a was synthesized according to the literature. ${ }^{20}$ The 4'-Iodo substituted benzylpiperidine derivatives ( 8 and $\mathbf{9})$ were synthesized as shown in Scheme 1. Alkylation of compound $3^{25}$ with ethyl bromoacetate gave 4 (71\% yield), followed by a bromo-to-tributyltin exchange reaction gave tributyltin derivative $\mathbf{5}$ for yields of $53 \%$. Compound 5 was allowed to react with iodine in $\mathrm{CCl}_{4}$ to give the iodo derivative 6 ( $68 \%$ yield). Compound 6 was hydrolyzed, followed by general amide coupling reaction with the corresponding phenylenediamines. Dehydration of the amidated products in acetic acid at reflux gave the benzimidazoles $\mathbf{7}$ and $\mathbf{9}$ for yields of $55 \%$ and $53 \%$, respectively. Compound 7 was converted to 8 by desmethylation with $\mathrm{HBr}$ (63\% yield). The target iodo phenoxypiperidine derivative (13) was synthesized as shown in Scheme 2. Phenoxypiperidine 11 was synthesized according to the method of Scheme 1 starting from compound $\mathbf{1 0}^{26}$ for yield of $45 \%$. Benzimidazole 12 was obtained by the same procedure for the synthesis of compound 7 for yield of $73 \%$. 
Finally, compound 12 was desmethylated by $\mathrm{BBr}_{3}$ to give 13 (77\% yield).

\subsection{In vitro binding assays}

The binding affinities ( $\mathrm{Ki}$ values) of benzimidazole derivatives for the NR2B subunit of NMDA receptor were evaluated with displacement studies of the typical NR2B antagonist, $\left[{ }^{3} \mathrm{H}\right]$ ifenprodil, to rat cortical synaptic membranes according to the literature. ${ }^{27}$ Trifluoroperazine was used to block the binding of $\left[{ }^{3} \mathrm{H}\right]$ ifenprodil in rat brain membranes to sites other than the NMDA receptors. As shown in Table 1, lead compound 1a showed excellent affinity $(K \mathrm{i}=3.09 \mathrm{nM})$ for the NR2B subunit, which was consistent with the results by using hNR1a/NR2B receptors expressed in Ltk- cells $(\mathrm{Ki}=1.50 \mathrm{nM})$ reported in the literature. ${ }^{20}$ Introduction of an iodine atom in $\mathrm{R}_{2}$ resulted in a slight reduction of binding affinity; however, high affinity for the NR2B subunit (Ki values; 7.28 and $5.75 \mathrm{nM}$ for $\mathbf{8}$ and $\mathbf{9}$, respectively) was maintained. On the other hand, phenoxypiperidine benzimidazole 13 exhibited a 4.5 -fold lower affinity $(\mathrm{Ki}=32.5$ $\mathrm{nM}$ ) than compound $\mathbf{8}$. These results suggested that the presence of phenoxypiperidine frame, instead of the benzylpiperidine, negatively influenced the in vitro binding affinity for this class of compound. In the recent report, the indole-carboxamide derivatives, with an oxygen atom substituted in the X-position, have several-fold lower affinity than the compounds with methylene group. On the contrary, comparable affinities were shown between benzimidazole-carboxamide derivatives substituted with methylene group and oxygen atom in X-position. ${ }^{22}$ Therefore, it might be difficult to fit the binding space for phenoxypiperidine derivatives in the NR2B antagonist binding site. Since 8 and 9 had high affinity for the NR2B subunit of the NMDA receptor, these ligands were selected to carry out further biological evaluations on the corresponding I-125-labeled probes.

\subsection{Radiochemistry}

Trimethyltin precursors 14 and $\mathbf{1 5}$ were synthesized from 8 and $\mathbf{9}$, respectively, by an iodo-to-trimethyltin exchange reaction (53\% yield for 14 and $97 \%$ yield for $\mathbf{1 5}$ ). To obtain $\left[{ }^{125} \mathrm{I}\right] \mathbf{8}$ and $\left[{ }^{125} \mathrm{I}\right] \mathbf{9}$, the corresponding trimethyltin precursors were allowed to react with $\left[{ }^{125} \mathrm{I}\right] \mathrm{NaI}$ (carrier-free) in the presence of $\mathrm{H}_{2} \mathrm{O}_{2}$ and $\mathrm{HCl}$ at room temperature for $40 \mathrm{~min}$ by a similar method in the literature ${ }^{28}$ (Scheme 3). The resulting I-125 labeled crude products were purified by HPLC. The radiochemical yields based on $\left[{ }^{125} \mathrm{I}\right] \mathrm{NaI}$ were $85-90$ and $78-81 \%$, for $\left[{ }^{125} \mathrm{I}\right] \mathbf{8}$ and $\left[{ }^{125} \mathrm{I}\right] \mathbf{9}$, respectively. 


\subsection{In vitro autoradiography}

In vitro regional distributions of $\left[{ }^{125} \mathrm{I}\right]$ benzimidazoles on the rat brain sections were evaluated by a method mentioned in the literature. ${ }^{13}$ As shown in the autoradiogram in Figure 3, both $\left[{ }^{125} \mathrm{I}\right] \mathbf{8}$ and $\left[{ }^{125} \mathrm{I}\right] \mathbf{9}$ showed high accumulation in the forebrain region (cerebral cortex, hippocampus), which is an NR2B-rich region, and lower uptake in the cerebellum, which is an NR2B-poor region (Fig. 3A and B). These distribution patterns were similar to $\left[{ }^{3} \mathrm{H}\right] \mathrm{CP}-101,606,{ }^{29}$ as well as to the mRNA distribution of the NR2B subunit. ${ }^{30}$ Nonspecific binding was determined in the presence of corresponding nonradioactive benzimidazoles $(10 \mu \mathrm{M})$, which resulted in a significant decrease in $\left[{ }^{125} \mathrm{I}\right] \mathbf{8}$ and $\left[{ }^{125} \mathrm{I}\right] \mathbf{9}$ accumulations in the forebrain region compared with total binding as visualized in Figure $3 \mathrm{C}$ and $\mathrm{D}$ and quantified in Figure $3 \mathrm{E}$ and $\mathrm{F}$, respectively. Almost no specific binding of both ligands exists in the cerebellum. The specific binding of $\left[{ }^{125} \mathrm{I}\right] \mathbf{8}$ was higher than $\left[{ }^{125} \mathrm{I}\right] \mathbf{9}$ in the forebrain regions (Fig. 3E and $\mathrm{F}$ ). These $\left[{ }^{125} \mathrm{I}\right]$ benzimidazoles showed similar binding property with C-11-labeled analog of CP-101,606, which is a high-affinity radioligand for the NR2B subunit. ${ }^{13}$ However, their specific bindings were lower than the $\left[{ }^{11} \mathrm{C}\right] \mathrm{CP}-101,606$ analog. The high lipophilic property of $\left[{ }^{125} \mathrm{I}\right] \mathbf{8}$ and $\left[{ }^{125} \mathrm{I}\right] \mathbf{9}$ was attributed to. The $\log D_{7.4}$ values of $\mathbf{8}$ and $\mathbf{9}$ were 3.95 and 3.54, respectively as shown in Table 1, which are higher than the $\left[{ }^{11} \mathrm{C}\right] \mathrm{CP}-101,606$ analog $(\log P=0.75)$.

In order to investigate the specific binding of $\left[{ }^{125} \mathrm{I}\right] \mathbf{8}$ and $\left[{ }^{125} \mathrm{I}\right] \mathbf{9}$ to the NR2B subunit of the NMDA ion channel, in vitro inhibition studies on rat brain region using Ro-25,6981 (NR2B antagonist) were carried out. Since it is reported that several ifenprodil-like antagonists bind to $\alpha 1$-adrenergic and $\sigma$ receptor, ${ }^{31,32}$ the effects of prazosin ( $\alpha_{1}$-adrenergic receptor antagonist) and DTG ( $\sigma$ receptor antagonist) in blocking these receptors in the inhibition studies were examined. In result, the in vitro bindings of $\left[{ }^{125} \mathrm{I}\right] \mathbf{8}$ and $\left[{ }^{125} \mathrm{I}\right] \mathbf{9}$ in the cerebral cortex and hippocampus were inhibited only by the NR2B selective antagonist, Ro-25,6981, as shown in Table 2. On the contrary, no ligands inhibited the bindings in the cerebellum. These results indicated that $\left[{ }^{125} \mathrm{I}\right] \mathbf{8}$ and $\left[{ }^{125} \mathrm{I}\right] \mathbf{9}$ selectively bind to the NR2B subunit. Therefore, this study attempted to carry out in vivo studies to validate the effectiveness of these $\left[{ }^{125} \mathrm{I}\right]$ benzimidazoles as SPECT imaging agents for the NR2B-subunit-containing NMDA receptor. 


\subsection{In vivo pharmacology}

The biodistribution studies of $\left[{ }^{125} \mathrm{I}\right] \mathbf{8}$ and $\left[{ }^{125} \mathrm{I}\right] \mathbf{9}$ were performed by using normal mice and the results were shown in Table 3. Initial brain uptake of $\left[{ }^{125} \mathrm{I}\right] \mathbf{8}$ was $0.21 \%$ $\mathrm{dose} / \mathrm{g}$ at $0.5 \mathrm{~min}$ after intravenous injection; whereas, the uptake of $\left[{ }^{125} \mathrm{I}\right] \mathrm{9}$ was $0.32 \%$ dose/g at the corresponding time. Both ligands showed very low brain to blood ratio (0.07) at $0.5 \mathrm{~min}$. Radioactivity of $\left[{ }^{125} \mathrm{I}\right] \mathbf{8}$ and $\left[{ }^{125} \mathrm{I}\right] 9$ in the brain increased with time and peaked at $180 \mathrm{~min}$ after administration $(0.56 \%$ and $0.67 \%$ dose $/ \mathrm{g}$, respectively). Accordingly, brain to blood ratio of these ligands rose to 1.99 and 1.23 at $180 \mathrm{~min}$, respectively. High hepatic uptake of $\left[{ }^{125} \mathrm{I}\right] \mathbf{8}$ and $\left[{ }^{125} \mathrm{I}\right] \mathbf{9}$ was observed, which peaked to $32.22 \%$ and $17.81 \%$ dose $/ \mathrm{g}$ at $180 \mathrm{~min}$, respectively. The amount of radioactivity of these tracers in the kidney was also high (5.35-12.20 and 3.26-15.23 \% dose/g, respectively). The distribution patterns in peripheral tissues could be attributed to the high lipophilic property of these $\left[{ }^{125} \mathrm{I}\right]$ benzimidazoles. These ligands showed almost homogenous brain distribution at 5-360 min after intravenous administration (Fig 4), which was inconsistent with the localization of expression of the NR2B subunit. The results for $\left[{ }^{125} \mathrm{I}\right]$ benzimidazoles were similar to other radioligands for the NR2B subunit. ${ }^{13-16}$ Metabolisms of $\left[{ }^{125} \mathrm{I}\right] \mathbf{8}$ and $\left[{ }^{125} \mathrm{I}\right] \mathbf{9}$ in the mouse brain were analyzed by radio-TLC of brain homogenates obtained at $180 \mathrm{~min}$ post-injection; and $77 \%$ and $85 \%$, respectively, of the parent compounds remained unchanged (data not shown). Thus, metabolism could have minimal effect the distribution pattern of $\left[{ }^{125} \mathrm{I}\right] \mathbf{8}$ and $\left[{ }^{125} \mathrm{I}\right] 9$. The results of this study showed that in vitro specific binding and in vivo brain uptake to blood radioactivity ratio of $\left[{ }^{125} \mathrm{I}\right] \mathbf{8}$ were higher than $\left[{ }^{125} \mathrm{I}\right] 9$. Therefore, in vivo experiments on $\left[{ }^{125} \mathrm{I}\right] \mathbf{8}$ were further performed.

The specificity of regional brain binding of $\left[{ }^{125} \mathrm{I}\right] \mathbf{8}$ for the NR2B subunit was studied by blocking studies using non-radioactive 8 and Ro-25,6981 (3 mg/kg, intravenously), which were administered $30 \mathrm{~min}$ prior to injection of the radioligand. Since brain uptake of $\left[{ }^{125} \mathrm{I}\right] \mathbf{8}$ peaked at $180 \mathrm{~min}$ as shown in Table 3 , regional brain distribution at $180 \mathrm{~min}$ after the radiotracer injection was determined. As shown in figure 5, pre-injection of non-radioactive $\mathbf{8}$ resulted in a significantly increased blood radioactivity of $\left[{ }^{125} \mathrm{I}\right] \mathbf{8}(\mathrm{P}<0.01)$ compared with the control group. Altogether, the liver uptake was significantly decreased $(\mathrm{P}<0.01)$. On the other hand, the brain uptake was increased slightly. Pre-administration of the NR2B selective antagonist, Ro-25,6981, had no effect on blood radioactivity of $\left[{ }^{125} \mathrm{I}\right] \mathbf{8}$. The hepatic uptake of $\left[{ }^{125} \mathrm{I}\right] \mathbf{8}$ was slightly increased but the regional brain uptake was slightly decreased. It should be noted that both groups treated with cold $\mathbf{8}$ and Ro-25,6981 showed a markedly lower brain to 
blood ratio of $\left[{ }^{125} \mathrm{I}\right] \mathbf{8}$ than the control group (Fig. 5D). Considering these results, $\left[{ }^{125} \mathrm{I}\right] \mathbf{8}$ could have specific binding component in the NR2B subunit under in vivo condition, which was similar to $\left[{ }^{11} \mathrm{C}\right]$ EMD-95885. ${ }^{16}$ However, both $\left[{ }^{125} \mathrm{I}\right] \mathbf{8}$ and $\left[{ }^{11} \mathrm{C}\right]$ EMD-95885 demonstrated reduced radioactivity in the NR2B poor region, cerebellum, even in the presence of NR2B ligands, which was unexplainable.

On the other hand, the brain uptake of commonly used PET radioligands, such as $\left[{ }^{11} \mathrm{C}\right]$ raclopride and $\left[{ }^{11} \mathrm{C}\right] \mathrm{DASB}$, was higher than $\left[{ }^{125} \mathrm{I}\right] \mathbf{8} .{ }^{33,34}$ Considering these facts, the brain permeability of $\left[{ }^{125} \mathrm{I}\right] \mathbf{8}$ could be inadequate for the visualization of NR2B subtype of the NMDA receptor by SPECT. All of the radioligands for NR2B subunit including benzidazoles in this report were inadequate $\mathrm{BBB}$ permeability. $\log \mathrm{P}$ ( or $\log \mathrm{D}_{7.4}$ ) values of $\left[{ }^{125} \mathrm{I}\right] \mathbf{8},\left[{ }^{125} \mathrm{I}\right] \mathbf{9}$ and ${ }^{11} \mathrm{C}$ labeled $\mathrm{CP}-101,606$ analog were $3.95,3.54$ and $0.75^{13}$. Log P values of 5-[3-(4- benzylpiperidin- 1-yl) prop-1-ynyl]-1,3- dihydrobenzoimidazol $-2-\left[{ }^{11} \mathrm{C}\right]$ one ${ }^{14}$ and $\left[{ }^{11} \mathrm{C}\right]$ EMD-95885 ${ }^{16}$ were not reported, however, calculated by ChemDraw Ultra to be 3.36 and 3.40, respectively. These ligands are not within the optimal range (1.0-3.0) for compounds expected to penetrate the BBB. ${ }^{35}$ Therefore log $\mathrm{P}$ value might be one of the reasons that the ligands showed low brain uptake. Another reason was thought to be high uptake of NR2B ligands in lung. The basic piperidine group in the ligands might cause these accumulation proclivities. Alternatively, lower molecular weight derivatives might be necessary to increase BBB permeability.

Another likely reason for the low uptake could be the excretion from brain tissue by the efflux systems of the BBB. It has been shown that many radioligands for mapping neuroreceptors are substrates for P-gp. ${ }^{36-38}$ It is reported that several acidic drugs are eliminated by the OAT from the brain across the BBB. ${ }^{24}$ Since the phenolic group in $\mathbf{8}$ has acidic moiety, there is a possibility that the brain uptake of $\left[{ }^{125} \mathrm{I}\right] \mathbf{8}$ is effluxed by OAT. Therefore, the effect of P-gp and OAT to the in vivo brain uptake of $\left[{ }^{125} \mathrm{I}\right] \mathbf{8}$ was analyzed.

Pretreatment with CsA (Cyclosporine A) (substrate of P-gp, $50 \mathrm{mg} / \mathrm{kg}$ ) or probenecid (substrate of OAT, $200 \mathrm{mg} / \mathrm{kg}$ ) by intravenous injection on mice tail vein 30 min before $\left[{ }^{125} \mathrm{I}\right] \mathbf{8}$ administration was followed by examination of biodistribution 180min later. As shown in Table 4, pretreatment with CsA resulted in the reduction of blood radioactivity level of $\left[{ }^{125} \mathrm{I}\right] \mathbf{8}$ but increase in the brain uptake in the CsA group compared with the control group. Therefore, the brain to blood ratio was 1.6-fold higher than the control group. Although P-gp is known to be present in the liver and kidney, ${ }^{39}$ the effect of CsA to the uptake of $\left[{ }^{125} \mathrm{I}\right] \mathbf{8}$ in the liver and kidney is nil. In contrast, pretreatment with probenecid increased the brain uptake but decreased the blood radioactivity level of $\left[{ }^{125} \mathrm{I}\right] \mathbf{8}$. The brain to blood ratio in the probenecid group was 
1.3-fold higher than the control group. The uptake of $\left[{ }^{125} \mathrm{I}\right] \mathbf{8}$ in the kidney was significantly reduced relative to the control group. The hepatic uptake of $\left[{ }^{125} \mathrm{I}\right] \mathbf{8}$, on the other hand, demonstrated no reduction by treatment with probenecid (Table 5). It is reported that probenecid is the substrate of OAT1 and 3. OAT1 is mainly expressed in the kidney and OAT3 in the kidney and brain. OATs play a role in the renal influx of probenecid. ${ }^{40,41}$ Therefore, this study indicated that $\left[{ }^{125} \mathrm{I}\right] \mathbf{8}$ may be a substrate of OATs in the brain and kidney. Although the extent of transport via P-gp and OAT is thought to be minimal, a certain amount of $\left[{ }^{125} \mathrm{I}\right] \mathbf{8}$ that enters the brain might serve as substrate of P-gp and OAT. Since it is reported that numerous structurally and pharmacologically unrelated lipophilic and amphipathic organic compounds are substrate of P-gp, ${ }^{42}$ the structural relationship between benzimidazoles and P-gp substrate is not elucidated. The introduction of a non-acidic group instead of a hydroxyl group in the benzimidazole skeleton of $\left[{ }^{125} \mathrm{I}\right] \mathbf{8}$ is expected to reduce the efflux by OAT. Furthermore, reduced lipophilic property of $\left[{ }^{125} \mathrm{I}\right] \mathbf{8}$ should be necessary to increase BBB permeability.

Another problem is the homogeneous distribution of $\left[{ }^{125} \mathrm{I}\right] \mathbf{8}$ and $\left[{ }^{125} \mathrm{I}\right] \mathbf{9}$ observed in the brain tissues under in vivo condition, which was quite different from in vitro results. Various factors might be present under in vivo condition such as nonspecific binding to capillary endothelial cells or other region. It is unclear whether the radioactivity of regional brain is present in the target site or peripheral sites. However the benzimidazoles with optimized log $\mathrm{P}$ values might decrease an accumulation in peripheral region.

Similar to this study, previously reported imaging agents for NR2B subunit of NMDA receptor showed consistent accumulation pattern with the expression of NR2B subunit and high specificity to NR2B rich region only under in vitro condition but not in vivo. ${ }^{13-19}$ Moreover, similar binding characters were observed in the radioligands for other binding sites of NMDA receptor, such as ion-channel site ${ }^{43,44}$ and glycine site ${ }^{45-47}$. Kew et. al. suggested that ifenprodil might exhibit higher affinity for the agonist-bound activated and desensitized states of the NMDA receptor, respectively, relative to the resting, agonist-unbound state. ${ }^{48}$ Furthermore, Mott et. al. demonstrated that NR2B antagonists were much more potent as a neuroprotectant at $\mathrm{pH} 6.5$ than at $\mathrm{pH} 7.5{ }^{48}$ The $\mathrm{pH}$ of ischemic tissue is as low as 6.5. ${ }^{50}$ In like manner, it is reported that $\left[{ }^{125} \mathrm{I}\right] \mathrm{CNS}-1261$, a radioligand for ion-channel site of NMDA receptor, showed higher uptake in the ischemic rat brain than normal region. ${ }^{51}$ In lieu with these reports, it is conjectured that the different biodistribution patterns of radioligands for the NR2B subtype of the NMDA receptor could be observed between normal condition and overactivated state, such as pathological stage. 
Since $\left[{ }^{125} \mathrm{I}\right] \mathbf{8}$ and $\left[{ }^{125} \mathrm{I}\right] \mathbf{9}$ showed low brain uptake and homogeneous brain distribution, these ligands were unsuitable for SPECT imaging of cerebral NMDA receptors. However, it should be noted that $\left[{ }^{125} \mathrm{I}\right] \mathbf{8}$ may have specific binding component in the NR2B subunit in vivo. The present study indicated that benzimidazole derivatives may be potential lead compounds for developing novel imaging agents for the NR2B subtype of NMDA receptors. Further structure activity relationship studies are required.

\section{Conclusion}

Our study has developed high-affinity benzimidazole derivatives 8 and $\mathbf{9}$ as new SPECT ligand candidates for NR2B subunit of the NMDA receptor. In vitro autoradiography experiments demonstrated that $\left[{ }^{125} \mathrm{I}\right] \mathbf{8}$ and $\left[{ }^{125} \mathrm{I}\right] \mathbf{9}$ showed NR2B selective binding in the rat brain slices. Although $\left[{ }^{125} \mathrm{I}\right]$ benzimidazoles showed poor $\mathrm{BBB}$ permeability and inconsistent distribution with NR2B subunit, $\left[{ }^{125} \mathrm{I}\right] \mathbf{8}$ may be partially bound to the NR2B subunit under in vivo condition. Compound $\mathbf{8}$ may be a potential scaffold for further structural modification to develop novel imaging probes of cerebral NMDA receptors.

\section{Experimental Section}

\subsection{General information.}

${ }^{1} \mathrm{H}$ NMR spectra were recorded on a JNM-GSX-270WB spectrometer $(270 \mathrm{MHz}$; JEOL, Tokyo, Japan), using tetramethylsilane as an internal standard. Fast atom bombardment mass spectra (FAB-MS) were obtained on a JMS-AX505H spectrometer (JEOL). Electrospray ionization mass spectra (ESI-MS) were obtained on a TSQ 7000 (Thermo Fisher Scientific, California, USA). High-resolution mass spectra (HRMS) were obtained on a QSTAR ${ }^{\circledR}$ XL MS/MS System with the use of ESI. [ $\left.{ }^{125} \mathrm{I}\right] \mathrm{NaI}$ was purchased from MP Biomedicals (California, USA). All other chemicals used were reagent grade. All animals were supplied by Japan SLC (Hamamatsu, Japan). An automated gamma counter with a $\mathrm{NaI}(\mathrm{Tl})$ detector (ARC-2000; Aloka, Tokyo, Japan) was used to measure radioactivity. The present animal study was approved by the Animal Care and Use Committee of the Hamamatsu University School of Medicine. 


\subsubsection{Ethyl 2-\{4-(4-bromobenzyl)piperidin-1-yl\} acetate (4)}

To a solution of $\mathbf{3}^{23}(13.0 \mathrm{~g}, 51.15 \mathrm{mmol})$ in DMF $(8.0 \mathrm{ml})$, diisopropylethylamine $(10.65 \mathrm{ml}, 61.26 \mathrm{mmol})$ and ethyl bromoacetate $(6.84 \mathrm{ml}, 61.26 \mathrm{mmol})$ were added, and the reaction mixture was stirred at room temperature for $3 \mathrm{~h}$. EtOAc $(50 \mathrm{ml})$ was added to the mixture, and the organic layers were washed with aqueous $\mathrm{NaHCO}_{3}$ and brine, dried with $\mathrm{Na}_{2} \mathrm{SO}_{4}$, and evaporated to dryness. The crude product was chromatographed on silica gel with hexane/EtOAc $=2: 1$ to provide $4(12.4 \mathrm{~g}, 36.44 \mathrm{mmol}, 71 \%)$ as a colorless oil, ${ }^{1} \mathrm{H}$ NMR $\left(\mathrm{CDCl}_{3}\right) \delta$ : $7.38(2 \mathrm{H}, \mathrm{d}, \mathrm{J}=8.43 \mathrm{~Hz}), 7.01(2 \mathrm{H}, \mathrm{d}, \mathrm{J}=8.42 \mathrm{~Hz})$, $4.17(2 \mathrm{H}, \mathrm{q}, \mathrm{J}=7.33 \mathrm{~Hz}), 3.17(2 \mathrm{H}, \mathrm{s}), 2.90(2 \mathrm{H}, \mathrm{d}, \mathrm{J}=11.92 \mathrm{~Hz}), 2.48(2 \mathrm{H}, \mathrm{d}, \mathrm{J}=6.59$ $\mathrm{Hz}), 2.10(2 \mathrm{H}, \mathrm{t}, \mathrm{J}=11.54 \mathrm{~Hz}), 1.58-1.33(5 \mathrm{H}, \mathrm{m}), 1.26(3 \mathrm{H}, \mathrm{t}, \mathrm{J}=7.15 \mathrm{~Hz})$, ESI-MS $\mathrm{m} / \mathrm{z} ; 340(\mathrm{M}+\mathrm{H})^{+}$.

\subsubsection{Ethyl 2-\{4-(4-tributylstannylbenzyl)piperidin-1-yl\} acetate (5)}

To a solution of $4(5.0 \mathrm{~g}, 14.69 \mathrm{mmol})$ in toluene $(50 \mathrm{ml})$, bistributyltin $(14.7 \mathrm{ml}$, $29.38 \mathrm{mmol}$ ) and tetrakis (triphenylphosphine) palladium (509 $\mathrm{mg}, 0.44 \mathrm{mmol}$ ) were added, and the reaction mixture was refluxed for $36 \mathrm{~h}$. After cooling, the reaction mixture was filtered through celite. The filtrate was evaporated to dryness. The crude product was chromatographed on silica gel with hexane/EtOAc $=3: 1$ to provide 5 (4.30 g, $7.75 \mathrm{mmol}, 53 \%)$ as a colorless oil, ${ }^{1} \mathrm{H} \mathrm{NMR}\left(\mathrm{CDCl}_{3}\right) \delta: 7.35(2 \mathrm{H}, \mathrm{d}, \mathrm{J}=7.35 \mathrm{~Hz})$, $7.09(2 \mathrm{H}, \mathrm{d}, \mathrm{J}=7.90 \mathrm{~Hz}), 4.17(2 \mathrm{H}, \mathrm{q}, \mathrm{J}=7.16 \mathrm{~Hz}), 3.17(2 \mathrm{H}, \mathrm{s}), 2.91(2 \mathrm{H}, \mathrm{d}, \mathrm{J}=11.54$ $\mathrm{Hz}), 2.50(2 \mathrm{H}, \mathrm{d}, \mathrm{J}=6.61 \mathrm{~Hz}), 2.10(2 \mathrm{H}, \mathrm{t}, \mathrm{J}=11.43 \mathrm{~Hz}), 1.66-1.23(20 \mathrm{H}, \mathrm{m})$, 1.06-0.85 (15 H, m), FAB-MS m/z; $552(\mathrm{M}+\mathrm{H})^{+}$.

\subsubsection{Ethyl 2-\{4-(4-iodobenzyl)piperidin-1-yl\} acetate (6)}

To a stirred solution of 5 (2.85 g, $5.17 \mathrm{mmol})$ in carbon tetrachloride (135 $\mathrm{mL})$, $50 \mathrm{mM}$ solution of iodine in dry carbon tetrachloride $(135 \mathrm{~mL}, 6.72 \mathrm{mmol})$ was added dropwise, and the reaction mixture was allowed to stand at room temperature for $1 \mathrm{~h}$. The mixture was evaporated to dryness. The crude product was chromatographed on silica gel with hexane/EtOAc $=1: 1$ to provide $6(1.36 \mathrm{~g}, 3.51 \mathrm{mmol}, 68 \%)$ as a colorless oil, ${ }^{1} \mathrm{H}$ NMR $\left(\mathrm{CDCl}_{3}\right) \delta: 7.58(2 \mathrm{H}, \mathrm{d}, \mathrm{J}=8.33 \mathrm{~Hz}), 6.88(2 \mathrm{H}, \mathrm{d}, \mathrm{J}=8.33 \mathrm{~Hz})$, $4.17(2 \mathrm{H}, \mathrm{q}, \mathrm{J}=7.08 \mathrm{~Hz}), 3.17(2 \mathrm{H}, \mathrm{s}), 2.90(2 \mathrm{H}, \mathrm{d}, \mathrm{J}=11.54 \mathrm{~Hz}), 2.47(2 \mathrm{H}, \mathrm{d}, \mathrm{J}=6.41$ $\mathrm{Hz}), 2.10(2 \mathrm{H}, \mathrm{t}, \mathrm{J}=11.54 \mathrm{~Hz}), 1.62-1.34(5 \mathrm{H}, \mathrm{m}), 1.26(3 \mathrm{H}, \mathrm{t}, \mathrm{J}=7.16 \mathrm{~Hz})$, FAB-MS $\mathrm{m} / \mathrm{z} ; 388(\mathrm{M}+\mathrm{H})^{+}$. 


\subsubsection{2-\{[4-(4-Iodobenzyl)piperidin-1-yl]methyl\}-5-methoxybenzimidazole (7)}

Compound 6 (804 mg, $2.08 \mathrm{mmol})$ was dissolved in $6 \mathrm{M} \mathrm{HCl}(5 \mathrm{ml})$, and the mixture was heated to $100{ }^{\circ} \mathrm{C}$ for $1 \mathrm{~h}$. The reaction mixture was cooled and evaporated to dryness. The residue was dissolved in DMF $(6 \mathrm{ml})$, followed by EDC $(518 \mathrm{mg}, 2.70$ mmol), 1-hydroxy-7-azabenzotriazole (367 mg, $2.70 \mathrm{mmol})$, triethylamine (570 $\mu 1,4.16$ $\mathrm{mmol}$ ), and 4-methoxy-1,2-phenylenediamine $(287 \mathrm{mg}, 2.08 \mathrm{mmol})$. The reaction mixture was stirred at room temperature for $3 \mathrm{~h}$ followed by quenching with aqueous $\mathrm{NaHCO}_{3}$ and ethyl acetate. Organic layer was separated and washed by brine, dried with $\mathrm{Na}_{2} \mathrm{SO}_{4}$, and evaporated to dryness. The crude oil was dissolved in acetic acid (6 $\mathrm{ml}$ ) and heated to $140{ }^{\circ} \mathrm{C}$ for $4 \mathrm{~h}$. The reaction mixture was cooled and evaporated to dryness. The crude product was chromatographed on silica gel with $\mathrm{CHCl}_{3} / \mathrm{MeOH}=20$ : 1 to provide 7 (530 mg, $1.15 \mathrm{mmol}, 55 \%$ ) as a colorless oil, ${ }^{1} \mathrm{H}$ NMR $\left(\mathrm{CDCl}_{3}\right) \delta: 7.59$ $(2 \mathrm{H}, \mathrm{d}, \mathrm{J}=8.12 \mathrm{~Hz}), 7.46(1 \mathrm{H}, \mathrm{d}, \mathrm{J}=7.91 \mathrm{~Hz}), 7.04(1 \mathrm{H}, \mathrm{s}), 6.88(1 \mathrm{H}, \mathrm{d}, \mathrm{J}=8.12 \mathrm{~Hz})$, $6.87(1 \mathrm{H}, \mathrm{d}, \mathrm{J}=7.98 \mathrm{~Hz}), 3.85(5 \mathrm{H}, \mathrm{s}), 2.93(2 \mathrm{H}, \mathrm{d}, \mathrm{J}=12.18 \mathrm{~Hz}), 2.51(2 \mathrm{H}, \mathrm{d}, \mathrm{J}=6.41$ $\mathrm{Hz}), 2.21(2 \mathrm{H}, \mathrm{t}, \mathrm{J}=11.33 \mathrm{~Hz}), 1.68-1.25(5 \mathrm{H}, \mathrm{m})$, ESI-MS m/z; $462(\mathrm{M}+\mathrm{H})^{+}$.

\subsubsection{2-\{[4-(4-Iodobenzyl)piperidin-1-yl]methyl $\}$ benzimidazol-5-ol (8)}

Compound 7 (530 mg, $1.15 \mathrm{mmol}$ ) was dissolved in $\mathrm{HBr} / \mathrm{H}_{2} \mathrm{O}(48 \%, 10 \mathrm{ml})$, and the mixture was heated to $100{ }^{\circ} \mathrm{C}$ for $6 \mathrm{~h}$. The reaction mixture was cooled and evaporated to dryness. The crude product was chromatographed on silica gel with $\mathrm{CHCl}_{3} / \mathrm{MeOH} / \mathrm{NH}_{4} \mathrm{OH}=200: 10: 1$ to provide $8(324 \mathrm{mg}, 0.724 \mathrm{mmol}, 63 \%)$ as a white solid, $\mathrm{mp}=117-118^{\circ} \mathrm{C},{ }^{1} \mathrm{H}$ NMR $\left(\mathrm{CDCl}_{3}\right) \delta: 7.67(1 \mathrm{H}, \mathrm{dd}, \mathrm{J}=8.66,1.01 \mathrm{~Hz}), 7.63(2 \mathrm{H}$, d, J=8.55 Hz), 7.16-7.12 (2 H, m), $6.99(2 \mathrm{H}, \mathrm{d}, \mathrm{J}=8.34 \mathrm{~Hz}), 4.77(2 \mathrm{H}, \mathrm{s}), 3.63(2 \mathrm{H}, \mathrm{d}$, $\mathrm{J}=11.97), 3.26-3.17(1 \mathrm{H}, \mathrm{m}), 2.58(\mathrm{~d}, \mathrm{~J}=6.84 \mathrm{~Hz}), 1.95-1.90(4 \mathrm{H}, \mathrm{m}), 1.66-1.60(2 \mathrm{H}$, m), ESI-HRMS (m/z) calcd for $\mathrm{C}_{20} \mathrm{H}_{23} \mathrm{IN}_{3} \mathrm{O}, 448.0880(\mathrm{M}+\mathrm{H})^{+}$, obsd 448.0829.

\subsection{5.}

$N$-\{2-[4-(4-Iodobenzyl)-piperidin-1-ylmethyl]benzoimidazol-5-yl\}methanesulfonamide (9)

Using the above procedure for 7 with $N$-(3,4-diaminophenyl) methanesulfonamide ${ }^{20}$ the title compound 9 (27 mg, $\left.0.052 \mathrm{mmol}, 53 \%\right)$ was obtained as a white solid, $\mathrm{mp}=92-94{ }^{\circ} \mathrm{C},{ }^{1} \mathrm{H} \mathrm{NMR}\left(\mathrm{CD}_{3} \mathrm{OD}\right) \delta: 7.58(2 \mathrm{H}, \mathrm{d}, \mathrm{J}=8.34 \mathrm{~Hz}), 7.50$ $(1 \mathrm{H}, \mathrm{d}, \mathrm{J}=8.12 \mathrm{~Hz}), 7.49$ (1 H, dd, J=2.08, $0.48 \mathrm{~Hz}), 7.13$ (1 H, dd, J= 8.66, $2.04 \mathrm{~Hz})$, $6.93(2 \mathrm{H}, \mathrm{d}, \mathrm{J}=7.91 \mathrm{~Hz}), 3.75(2 \mathrm{H}, \mathrm{s}), 3.32(2 \mathrm{H}, \mathrm{d}, \mathrm{J}=10.47 \mathrm{~Hz}), 2.90(3 \mathrm{H}, \mathrm{s}), 2.50$ $(2 \mathrm{H}, \mathrm{d}, \mathrm{J}=6.62 \mathrm{~Hz}), 2.11(2 \mathrm{H}, \mathrm{t}, \mathrm{J}=10.69 \mathrm{~Hz}), 1.64-1.20(5 \mathrm{H}, \mathrm{m})$, ESI-HRMS (m/z) calcd for $\mathrm{C}_{21} \mathrm{H}_{26} \mathrm{IN}_{4} \mathrm{O}_{2} \mathrm{~S}, 525.0821(\mathrm{M}+\mathrm{H})^{+}$, obsd 525.0769. 


\subsubsection{Ethyl 2-\{4-(4-Iodophenoxy)piperidin-1-yl\} acetate (11)}

Compound 10 (686 mg, $1.70 \mathrm{mmol})^{25}$ was dissolved in $30 \% \mathrm{TFA} / \mathrm{CH}_{2} \mathrm{Cl}_{2}(5 \mathrm{ml})$, and the mixture was stirred at room temperature for $5 \mathrm{~h}$ followed by evaporated to dryness. The crude product was converted to the title compound $\mathbf{1 1}$ using the above procedure for compound 4. In result, compound 11 (300 $\mathrm{mg}, 45 \%)$ was obtained as a colorless oil, ${ }^{1} \mathrm{H}$ NMR $\left(\mathrm{CDCl}_{3}\right) \delta: 7.53(2 \mathrm{H}, \mathrm{d}, \mathrm{J}=8.98 \mathrm{~Hz}), 6.68(2 \mathrm{H}, \mathrm{d}, \mathrm{J}=8.98 \mathrm{~Hz})$, $4.30(1 \mathrm{H}$, quin, $\mathrm{J}=3.85 \mathrm{~Hz}), 4.19(2 \mathrm{H}, \mathrm{q}, \mathrm{J}=7.09 \mathrm{~Hz}), 3.24(2 \mathrm{H}, \mathrm{s}), 2.83-2.75(2 \mathrm{H}, \mathrm{m})$, 2.58-2.47 (2 H, m), 2.05-1.97 (2 H, m), 1.91-1.84 (2 H, m), ESI-MS m/z; $390(\mathrm{M}+\mathrm{H})^{+}$.

\subsubsection{2-\{[4-(4-Iodophenoxy)piperidin-1-yl]methyl\}-5-methoxybenzimidazole (12)}

Using the above procedure for 7 starting from compound 11, the title compound 12 (96 mg, $0.207 \mathrm{mmol}, 73 \%$ ) was obtained as a yellow solid, $\mathrm{mp}=50-52{ }^{\circ} \mathrm{C},{ }^{1} \mathrm{H} \mathrm{NMR}$ $\left(\mathrm{CD}_{3} \mathrm{OD}\right) \delta: 7.53(2 \mathrm{H}, \mathrm{d}, \mathrm{J}=8.97 \mathrm{~Hz}), 7.41(1 \mathrm{H}, \mathrm{d}, \mathrm{J}=8.76 \mathrm{~Hz}), 7.04(1 \mathrm{H}, \mathrm{d}, \mathrm{J}=2.13$ $\mathrm{Hz}), 6.86(1 \mathrm{H}, \mathrm{dd}, \mathrm{J}=8.76,2.57 \mathrm{~Hz}), 6.73(2 \mathrm{H}, \mathrm{d}, \mathrm{J}=8.98 \mathrm{~Hz}), 4.38(1 \mathrm{H}$, quin, $\mathrm{J}=3.74$ $\mathrm{Hz}), 3.83$ (3 H, s), 3.79 (2 H, s), 2.85-2.77 (2 H, m), 2.51-2.41 (2 H, m), 2.07-1.98 (2 H, m), 1.87-1.77 (2 H, m), ESI-MS m/z; $164(\mathrm{M}+\mathrm{H})^{+}$.

\subsubsection{2-\{[4-(4-Iodophenoxy)piperidin-1-yl]methyl\}benzimidazol-5-ol (13)}

Using the above procedure for $\mathbf{8}$ starting from compound $\mathbf{1 2}$, the title compound 13 (108 mg, $0.241 \mathrm{mmol}, 77 \%$ ) was obtained as a white solid, $\mathrm{mp}=63-65{ }^{\circ} \mathrm{C},{ }^{1} \mathrm{H} \mathrm{NMR}$ $\left(\mathrm{CD}_{3} \mathrm{OD}\right) \delta: 7.53(2 \mathrm{H}, \mathrm{d}, \mathrm{J}=8.98 \mathrm{~Hz}), 7.34(1 \mathrm{H}, \mathrm{d}, \mathrm{J}=8.55 \mathrm{~Hz}), 6.90(1 \mathrm{H}, \mathrm{d}, \mathrm{J}=2.25$ $\mathrm{Hz}), 6.74(1 \mathrm{H}, \mathrm{dd}, \mathrm{J}=8.45,2.68 \mathrm{~Hz}), 6.73(2 \mathrm{H}, \mathrm{d}, \mathrm{J}=8.97 \mathrm{~Hz}), 4.38(1 \mathrm{H}$, quin, $\mathrm{J}=3.63$ $\mathrm{Hz}), 3.76$ (2 H, s), 2.86-2.76 (2 H, m), 2.49-2.41 (2 H, m), 2.07-1.99 (2 H, m), 1.86-1.77 $(2 \mathrm{H}, \mathrm{m})$, ESI-HRMS (m/z) calcd for $\mathrm{C}_{19} \mathrm{H}_{21} \mathrm{IN}_{3} \mathrm{O}_{2}, 450.679(\mathrm{M}+\mathrm{H})^{+}$, obsd 450.0621 .

\subsubsection{2-\{[4-(4-Trimethylstannylbenzyl)piperidin-1-yl]methyl $\}$ benzimidazol-5-ol (14)}

To a solution of $8(50 \mathrm{mg}, 0.125 \mathrm{mmol})$ in toluene $(3 \mathrm{ml})$, bistrimethyltin $(104 \mu \mathrm{l}$, $0.502 \mathrm{mmol}$ ) and tetrakis (triphenylphosphine) palladium (15 $\mathrm{mg}, 0.013 \mathrm{mmol}$ ) were added, and the reaction mixture was refluxed for $6 \mathrm{~h}$. After cooling, the reaction mixture was filtered through celite. The filtrate was evaporated to dryness. The crude product was chromatographed on silica gel with $\mathrm{CHCl}_{3} / \mathrm{MeOH}=15: 1$ to provide 14 (32 $\mathrm{mg}$, $0.066 \mathrm{mmol}, 53 \%)$ as a colorless oil, ${ }^{1} \mathrm{H} \mathrm{NMR}\left(\mathrm{CDCl}_{3}\right) \delta: 7.41(1 \mathrm{H}, \mathrm{d}, \mathrm{J}=8.80 \mathrm{~Hz})$, $7.39(2 \mathrm{H}, \mathrm{d}, \mathrm{J}=8.06 \mathrm{~Hz}), 7.08(2 \mathrm{H}, \mathrm{d}, \mathrm{J}=7.69 \mathrm{~Hz}), 7.04(1 \mathrm{H}, \mathrm{d}, \mathrm{J}=2.20 \mathrm{~Hz})$,

$6.83(1 \mathrm{H}, \mathrm{dd}, \mathrm{J}=8.80,2.20 \mathrm{~Hz}), 4.09(2 \mathrm{H}, \mathrm{s}), 3.11(2 \mathrm{H}, \mathrm{d}, \mathrm{J}=12.09 \mathrm{~Hz}), 2.53(2 \mathrm{H}, \mathrm{d}$, $\mathrm{J}=5.87 \mathrm{~Hz}), 2.47(2 \mathrm{H}, \mathrm{t}, \mathrm{J}=11.73 \mathrm{~Hz}), 1.77-1.51(5 \mathrm{H}, \mathrm{m}), 0.27(9 \mathrm{H}, \mathrm{s})$, FAB-MS m/z; $486(\mathrm{M}+\mathrm{H})^{+}$. 


\subsubsection{0. $\quad N$-\{2-[4-(4-Trimethylstannylbenzyl)-piperidin-1-ylmethyl]benzoimidazol-}

\section{5-yl\}- methanesulfonamide (15)}

Using the above procedure for $\mathbf{1 4}$ starting from compound $\mathbf{9}$, the title compound $15(5.2 \mathrm{mg}, 9.26 \mu \mathrm{mol}, 97 \%)$ was obtained as a colorless oil, ${ }^{1} \mathrm{H}$ NMR $\left(\mathrm{CDCl}_{3}\right) \delta$ : 7.57-7.53 (2 H, m), 7.40 (2 H, d, $7.91 \mathrm{~Hz}), 7.18(1 \mathrm{H}, \mathrm{d}, 8.33 \mathrm{~Hz}), 7.10(2 \mathrm{H}, \mathrm{d}, 7.70 \mathrm{~Hz})$, $3.78(2 \mathrm{H}, \mathrm{s}), 2.97(3 \mathrm{H}, \mathrm{s}), 2.86(2 \mathrm{H}, \mathrm{d}, \mathrm{J}=11.12 \mathrm{~Hz}), 2.54(2 \mathrm{H}, \mathrm{d}, \mathrm{J}=6.62 \mathrm{~Hz}), 2.14(2$ $\mathrm{H}, \mathrm{t}, \mathrm{J}=10.15 \mathrm{~Hz}), 1.41-1.22(5 \mathrm{H}, \mathrm{m}), 0.27(9 \mathrm{H}, \mathrm{s}), \mathrm{FAB}-\mathrm{MS} \mathrm{m} / \mathrm{z} ; 563(\mathrm{M}+\mathrm{H})^{+}$.

\subsection{Radiosynthesis}

$\left[{ }^{125} \mathrm{I}\right] \mathbf{8}$ and $\left[{ }^{125} \mathrm{I}\right] \mathbf{9}$ were prepared by similar method described in the literature. ${ }^{26} \mathrm{In}$ brief, $30 \%$ aqueous hydrogen peroxide $(100 \mu \mathrm{l})$ was added to a mixture of $\left[{ }^{125} \mathrm{I}\right] \mathrm{NaI}$ (60 $\mu 1,19.4-41.4 \mathrm{MBq}$, carrier-free), $1 \% \mathrm{HCl}(40 \mu \mathrm{l})$, and trimethylstannyl precursor 14, $15(0.1 \mathrm{mg}$ in $100 \mu \mathrm{l}$ of ethanol) in a sealed vial. The mixture was allowed to react for $40 \mathrm{~min}$ at room temperature and then quenched with $10 \%$ aqueous sodium bisulfite $(100 \mu \mathrm{l})$. EtOAc $(5 \mathrm{ml})$ was added to the mixture, and the organic layers were washed with aqueous brine, and evaporated to dryness. The crude products were purified by HPLC (column; Nacalai Cosmosil 5C18-AR II, 10×250 mm, mobile phase; $\mathrm{MeOH}$ : $0.1 \%$ TFA in $\mathrm{H}_{2} \mathrm{O}=60: 40$, flow rate: $3.0 \mathrm{ml} / \mathrm{min}$ ). Each fraction was collected and the solvent was removed in vacuo. Radiochemical purity was assayed to be $>98 \%$ by analytical HPLC (column; Nacalai Cosmosil 5C18-ARII, $4.6 \times 250 \mathrm{~mm}$, mobile phase; MeOH: $0.1 \%$ TFA in $\mathrm{H}_{2} \mathrm{O}=55: 45$, flow rate: $1.0 \mathrm{ml} / \mathrm{min}$ ). The radiochemical yields based on $\left[{ }^{125} \mathrm{I}\right] \mathrm{NaI}$ were $85-90$ and $78-81 \%$ for $\left[{ }^{125} \mathrm{I}\right] \mathbf{8}$ and $\left[{ }^{125} \mathrm{I}\right] \mathbf{9}$, respectively.

\subsection{In vitro binding assays}

The $K \mathrm{i}$ values of benzimidazoles for binding of $\left[{ }^{3} \mathrm{H}\right]$ ifenprodil to rat cortical membrane homogenates were determined by the method mentioned in the literature. ${ }^{25}$ In brief, well washed membranes (200-300 $\mu \mathrm{g}$ of protein) in $20 \mathrm{mM}$ HEPES-KOH buffer ( $\mathrm{pH} 7.4)$, were incubated with $\left[{ }^{3} \mathrm{H}\right]$ ifenprodil $(4.0 \mathrm{nM})$ with either buffer or displacing drug added to make a final volume of $500 \mu \mathrm{l}$ for $120 \mathrm{~min}$ at $25^{\circ} \mathrm{C}$. In each experiment the assay buffer contained $100 \mathrm{mM}$ trifluoroperazine. Non-specific binding was defined by the addition of unlabeled ifenprodil at $1 \mathrm{mM}$. Bound ligands were collected by rapid filtration using a Brandel cell harvester onto glass fiber filter (GF/B). The filters were washed rapidly three times with $2.5 \mathrm{ml}$ of ice-cold assay buffer. Following separation and rinsed, the filters were placed into scintillation liquid (4 ml; 
ASCII, GE Healthcare Bio-Sciences) and radioactivity was determined with a liquid scintillation counter.

\subsection{In vitro receptor autoradiography}

The brain sagittal sections, obtained by the method described in the literature, ${ }^{13}$ were pre-incubated for $30 \mathrm{~min}$ at $25{ }^{\circ} \mathrm{C}$ in $50 \mathrm{mM}$ Tris- $\mathrm{HCl}$ buffer ( $\mathrm{pH} 7.4$ at $25^{\circ} \mathrm{C}$ ) containing $5 \%$ bovine serum albumin (BSA). These were subsequently incubated in the same buffer containing $\left[{ }^{125} \mathrm{I}\right] \mathbf{8}$ or $\left[{ }^{125} \mathrm{I}\right] 9(300 \mathrm{kBq}, 0.09-0.14 \mathrm{nM})$ at $25{ }^{\circ} \mathrm{C}$ for $30 \mathrm{~min}$. The slices were rinsed triplicate for 3 min each with cold $\left(5^{\circ} \mathrm{C}\right)$ incubation buffer containing $1 \%$ BSA, and subsequently dipped into cold water. The sections were dried under a steam of warm air and placed in contact with ${ }^{125}$ I-sensitive imaging plates (BAS-SR 2040; Fuji Photo. Film, Tokyo, Japan) for 3 days. Distributions of radioactivity on the plates were analyzed by Bio-Image Analyzer (FLA-3000; Fuji Photo. Film, Tokyo, Japan), which were photographically visualized as shown in Figure 2A-D. Regions of interest (ROIs) on the slices were placed on the cerebral cortex, hippocampus, and cerebellum; and the radioactivities in these regions were expressed as photostimulated luminescence (PSL) values on ROI-background PSL value per square millimeter. The specific binding was determined as the difference between total binding and binding in the presence of the corresponding non-radioactive benzimidazoles (10 $\mu \mathrm{M})$. Receptor selectivity studies were performed as similar procedure in the presence of several drugs $(10 \mu \mathrm{M})$.

\subsection{In vivo experiments}

The $\left[{ }^{125} \mathrm{I}\right]$ benzimidazoles $(0.1 \mathrm{ml}$, ca. $14.8 \mathrm{kBq}$ for whole body distribution studies, ca. $148 \mathrm{kBq}$ for regional brain distribution studies) were injected intravenously via tail vein into ddY mice (Male, $6 \mathrm{~W}, 30-35 \mathrm{~g}$ ). At the designated time intervals, the mice were killed and their organs were dissected. The brain was further divided into the cerebral cortex, hippocampus and cerebellum. The tissues were then weighed and the radioactivity was measured by automated gamma counting. Data were calculated as the percentage of the injected dose per gram of tissue (\%dose $/ \mathrm{g})$.

To assess the in vivo specific binding of $\left[{ }^{125} \mathrm{I}\right] \mathbf{8}$, the non-radioactive $\mathbf{8}$ or NR2B antagonist Ro-25,6981 (3 mg/kg in $10 \% \mathrm{DMSO} / \mathrm{saline})$ was given as pre-treatment by intravenous injection $30 \mathrm{~min}$ before $\left[{ }^{125} \mathrm{I}\right] \mathbf{8}$ administration. Mice were killed $180 \mathrm{~min}$ after injection. The modulation of $\left[{ }^{125} \mathrm{I}\right] \mathbf{8}$ by $\mathrm{P}$-gp and OAT in vivo was evaluated 
according to the literature. ${ }^{36,52,53}$ In brief, CsA $\{50 \mathrm{mg} / \mathrm{kg}$ in a mixture of cremophor EL $(140 \mathrm{mg} / \mathrm{ml})$ and ethanol $(5 \%) /$ saline $\}$ or probenecid $(200 \mathrm{mg} / \mathrm{kg}$ in $5 \%$ sodium bicarbonate/saline) was given as pre-treatment by intravenous injection $30 \mathrm{~min}$ before $\left[{ }^{125} \mathrm{I}\right] \mathbf{8}$ administration. Mice were killed $180 \mathrm{~min}$ after injection of $\left[{ }^{125} \mathrm{I}\right] \mathbf{8}$. In each of the control mouse, the same amount of drug-free corresponding solvent was injected.

To assess the metabolism of $\left[{ }^{125} \mathrm{I}\right]$ benzimidazoles in the mouse brain, the mice were killed at $180 \mathrm{~min}$ after $\left[{ }^{125} \mathrm{I}\right]$ benzimidazoles $(185 \mathrm{kBq})$ injection. Whole brains were quickly removed, homogenized with ice-cooled $\mathrm{MeOH}(1.0 \mathrm{ml})$, and centrifuged at $1,750 \mathrm{~g}$ for $10 \mathrm{~min}$ at $4{ }^{\circ} \mathrm{C}$. The metabolites in $\mathrm{MeOH}$ extract were analyzed by radio-TLC using $\mathrm{CHCl}_{3} / \mathrm{MeOH}=9: 1$ and EtOAc: $\mathrm{EtOH}=1: 1$ for $\left[{ }^{125} \mathrm{I}\right] \mathbf{8}, \mathrm{CHCl}_{3} / \mathrm{EtOH}$ $=4: 1$ and EtOAc: $\mathrm{EtOH}=4: 1$ for $\left[{ }^{125} \mathrm{I}\right]$ 9, as mobile phases.

\subsection{Partition coefficient determination}

Partition coefficient between n-octanol and buffer was measured by a conventional shake flask method in triplicate. The benzimidazoles (1-2 mg) were well

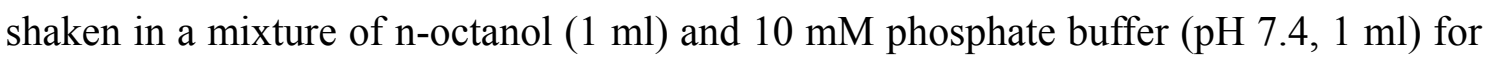
$15 \mathrm{~min}$ at ambient temperature. After centrifugation ( $2500 \mathrm{rpm}$ for $5 \mathrm{~min}$ ) of the mixture, the two layers were separated and analyzed by HPLC (column; Nacalai Cosmosil $5 \mathrm{C}_{18}$-AR 300, $4.6 \times 250 \mathrm{~mm}$, mobile phase; $\mathrm{MeOH}: 0.1 \%$ TFA in $\mathrm{H}_{2} \mathrm{O}=50$ : 50, flow rate; $1.0 \mathrm{ml} / \mathrm{min}$ ) to obtain $\log D(\mathrm{pH} 7.4)$ values (Table 1$)$.

\subsection{Data analysis}

Data were expressed as the mean \pm standard deviation. In vitro experiments of $\left[{ }^{125} \mathrm{I}\right] \mathbf{8}$ and $\left[{ }^{125} \mathrm{I}\right] \mathbf{9}$ were statistically analyzed by Mann-Whitney U-test as shown in Figure 2. In vivo experiments of $\left[{ }^{125} \mathrm{I}\right] \mathbf{8}$ were analyzed by the Kruskal-Wallis test with Dunn's multiple comparison post-test as shown in Figure 4 or Mann-Whitney U-test as shown in Table 4 . A value of $\mathrm{P}<0.05$ was considered statistically significant.

\section{Acknowledgement}

The authors gratefully acknowledge our colleague, Mutsumi Kosugi, for her technical help in the animal experiments. This work was supported by the Grant-in-Aid for Young Scientists (Start-up) (18890080) and Hamamatsu University School of Medicine Research Grant for Young Researchers. 


\section{Reference}

1. Danysz, W.; Parsons, C. G.; Pharmacol. Rev., 1998, 50, 597.

2. Rothman, S. M.; Olney, J. W. Ann. Neurol., 1986, 19, 105.

3. Meldrum, B.; Garthwaite, J. Trends Pharmacol. Sci., 1990, 11, 379.

4. Francis, P. T.; Sims, N. R.; Procter, A. W.; Bowen, D. M. J. Neurochem., 1993, 60, 1589.

5. Beal, M. F.; Swartz, K. J.; Isacson, O. Dev Brain Res., 1992, 68, 136.

6. Moore, H.; West, A. R.; Grace, A. A. Biol. Psychiatry, 1999, 46, 40.

7. Dingledine, R.; Borges, K.; Bowie, D.; Traynelis, S. F. Pharmacol. Rev., 1999, 51, 7.

8. Masu, M.; Nakajima, Y.; Moriyoshi, K.; Ishii, T.; Akazawa, C.; Nakanashi, S. Ann. N.

Y. Acad. Sci., 1993, 707, 153.

9. Loftis, J. M.; Janowsky, A. Pharmacology \& Therapeutics, 2003, 97, 55.

10. Liu, Y.; Wong, T. P.; Aarts, M.; Rooyakkers, A.; Liu, L.; Lai, T. W.; Wu, D. C.; Lu, J.; Tymianski, M.; Craig, A. M.; Wang, Y. T. J. Neurosci., 2007, 27, 2846.

11. DeRidder, M. N.; Simon, M. J.; Siman, R.; Auberson, Y. P.; Raghupathi, R.; Meaney,

D. F. Neurobiol. Dis., 2006, 22, 165.

12. Zhou, M.; Baudry, M. J. Neurosci., 2006, 26, 2956.

13. Haradahira, T.; Maeda, J.; Okauchi, T.; Zhang, M. R.; Hojo, J.; Kida, T.; Arai, T.; Yamamoto, F.; Sasaki, S.; Maeda, M.; Suzuki, K.; Suhara, T. Nucl. Med.Biol., 2002, 29, 517.

14. Roger, G.; Lagnel, B.; Besret, L.; Bramoullé, Y.; Coulon, C.; Ottaviani, M.; Kassiou, M.; Bottlaender, M.; Valette, H.; Dollé, F. Bioorg. Med.Chem., 2003, 11, 5401.

15. Dollé, F.; Valette, H.; Demphel, S.; Coulon, C.; Ottaviani, M.; Bottlaender, M.; Kassiou, M. J. Labelled Cpd. Radiopharm., 2004, 47, 911.

16. Roger, G.; Dollé, F.; Bruin, B.; Liu, X.; Besret, L.; Bramoullé, Y.; Coulon, C.; Ottaviani, M.; Bottlaender, M.; Valette, H.; Kassiou, M. Bioorg. Med. Chem., 2004, 12 , 3229 .

17. Haradahira, T.; Okauchi, J.; Maeda, J.; Suzuki, K.; Suhara, T. J. Nucl. Med., 2004, 45, 441P.

18. Haradahira, T.; Fuchigami, T.; Fujimoto, N.; Okauchi, T.; Maeda, J.; Suzuki, K.; Suhara, T.; Yamamoto, F.; Mukai, T.; Maeda, M. J. Label. Compd. Radiopharm., 2005, 48, Suppl. 1, S92.

19. Arstad, E; Platzer, S; Berthele, A.; Pilowsky, L. S.; Luthra, S. K.; Wester, H. J.; Henriksen, G. Bioorg. Med. Chem., 2006, 14, 6307.

20. McCauley, J. A.; Theberge, C. R.; Romano, J. J.; Billings, S. B.; Anderson, K. D.; 
Claremon, D. A.; Freidinger, R. M.; Bednar, R. A.; Mosser, S. D.; Gaul, S. L. J Med Chem., 2004, 47, 2089.

21. Borza, I.; Kolok, S.; Gere, A.; Nagy, J.; Fodor, L.; Galgóczy, K.; Fetter, J.; Bertha, F.; Agai, B.; Horváth, C.; Farkas, S.; Domány, G. Bioorg. Med. Chem. Lett., 2006, 16, 4638 .

22. Borza, I.; Bozó, E.; Barta-Szalai, G.; Kiss, C.; Tárkányi, G.; Demeter, A.; Gáti, T.; Háda, V.; Kolok, S.; Gere, A.; Fodor, L.; Nagy, J.; Galgóczy, K.; Magdó, I.; Agai, B.; Fetter, J.; Bertha, F.; Keserü, G. M.; Horváth, C.; Farkas, S.; Greiner, I.; Domány, G.. J Med Chem., 2007, 50, 901.

23. Matsumoto, R.; Haradahira, T.; Ito, H.; Fujimura, Y.; Seki, C.; Ikoma, Y.; Maeda, J.; Arakawa, R.; Takano, A.; Takahashi, H.; Higuchi, M.; Suzuki, K.; Fukui, K.;

Suhara, T., Synapse, 2007, 61, 795.

24. Kikuchi, R.; Kusuhara, H.; Sugiyama, D.; Sugiyama, Y. J. Pharmacol. Exp. Ther., 2003, 306, 51 .

25. Ting, P. C.; Lee, J. F.; Wu J.; Umland S. P.; Aslanian R.; Cao J.; Dong, Y.; Garlisi C. G.; Gilbert, E. J.; Huang, Y.; Jakway, J.; Kelly, J.; Liu, Z.; McCombie, S.; Shah, H.; Tian, F.; Wan, Y.; Shih, N. Y. Bioorg. Med. Chem. Lett., 2005, 15, 1375.

26. Kimball, F. S.; Romero, F. A.; Ezzili, C.; Garfunkle, J.; Rayl, T. J.; Hochstatter, D. G.; Hwang, I.; Boger, D. L. J. Med. Chem., 2008, 51, 937.

27. Coughenour, L. L.; Barr, B. M. J. Pharmacol. Exp. Ther. 2001, 296, 150.

28. Hirata, M.; Mori, T.; Soga, S.; Umeda, T.; Ohmomo, Y. Chem. Pharm. Bull., 2006, 54,470 .

29. Menniti, F.; Chenard, B.; Collins, M.; Ducat, M.; Shalaby, I.; White, F. Eur. J. Pharmacol, 1997, 331, 117.

30. Mori, H; Mishina, M. Neuropharmacol, 1995, 34, 1219.

31. Chenard, B. L.; Shalaby, I. A.; Koe, B. K.; Ronau, R. T.; Butler, T. W.; Prochniak, M. A.; Schmidt, A. W.; Fox, C. B. J. Med. Chem., 1991, 34, 3085.

32. Karbon, E. W.; Patch, R. J.; Pontecorvo, M. J.; Ferkany, J. W. Eur. J. Pharmacol., 1990, 176, 247.

33. Slifstein, M.; Hwang, D. R.; Martinez, D.; Ekelund, J.; Huang, Y.; Hackett, E.; Abi-Dargham, A.; Larelle, M. J. Nucl. Med., 2006, 47, 313.

34. Frankle, W. G.; Slifstein, M.; Gunn, R. N.; Huang, Y.; Hwang, D. R.; Darr, E. A.; Narendran, R.; Abi-Dargham, A., Laruelle, M. J. Nucl. Med., 2006, 47, 815.

35. Dischino, D. D.; Welch, M. J.; Kilbourn, M. R.; Raichle, M. E. J. J. Nucl. Med. 1983, 24, 1030.

36. Ishiwata, K.; Kawamura, K.; Yanai, K.; Hendrikse, N. H. J. Nucl. Med. 2007, 48, 
81.

37. Laćan, G. Plenevaux, A. Rubins, D. J. Way, B. M. Defraiteur, C. Lemaire, C. Aerts, J. Luxen, A. Cherry, S. R. Melega, W. P. Eur. J. Nucl. Med. Mol. Imaging., 2008, 35, 2256.

38. Nojiri, Y.; Ishiwata, K.; Qinggeletu; Tobiishi, S.; Sasada, T.; Yamamoto, F.; Mukai, T.; Maeda, M. Biol. Pharm. Bull., 2008, 31, 1274.

39. Mizuno, N.; Niwa, T.; Yotsumoto, Y.; Sugiyama, Y.; Pharmacol. Rev., 2003, 55, 425.

40. Zhou, F.; You, G.; Pharm. Res., 2007, 24, 28.

41. Masereeuw, R.; Russel, F. G.; Pharmacol. Ther, 2010, 126, 200.

42. Zhou, S.; Lim, L. Y.; Chowbay, B. Drug Metab. Rev., 2004, 36, 57.

43. Orita, K.; Sasaki, S.; Maeda, M.; Hashimoto, A.; Nishikawa, T.; Yugami, T.;

Umezu,K., 1993, Nucl. Med.Biol.,20, 865.

44. Haradahira, T.; Sasaki, S.; Maeda, M.; Kobayashi, K.; Inoue, O.; Tomita, U.; Nishikawa, T.; Suzuki, K. J. Labelled Cpd. Radiopharm., 1998, 41, 843.

45. Haradahira, T.; Zhang, M. R.; Maeda, J.; Okauchi, T.; Kawabe, K.; Kida, T.; Suzuki, K.; Suhara, T. Nucl. Med. Biol., 2000, 27, 357.

46. Fuchigami, T.; Haradahira, T.; Fujimoto, N.; Okauchi, T.; Maeda, J.; Suzuki, K.; Suhara, T.; Yamamoto, F.; Sasaki, S.; Mukai, T.; Yamaguchi, H.; Ogawa, M.; Magata, Y.; Maeda, M. Nucl. Med. Biol., 2008, 35, 203.

47. Fuchigami T, Haradahira T, Fujimoto N, Nojiri Y, Mukai T, Yamamoto F, Okauchi T, Maeda J, Suzuki K, Suhara T, Yamaguchi H, Ogawa M, Magata Y, Maeda M., Bioorg. Med. Chem., 2009, 17, 5665.

48. Kew J. N., Trube G., Kemp J. A.; J. Physiol., 1996, 497, 761.

49. Mott D. D., Doherty J. J., Zhang S., Washburn M. S., Fendley M. J., Lyuboslavsky P., Traynelis S. F., Dingledine R., Nat Neurosci., 1998 Dec;1(8):659.

50. Silver I. A., Erecinska M., J. Cereb. Blood Flow Metab., 1992, 12, 759.

50. Owens, J.; Tebbutt, A. A.; McGregor, A. L.; Kodama, K.; Magar, S. S.; Perlman, M. E.; Robins, D. J.; Durant, G. J.; McCulloch, J. Nucl. Med. Biol., 2000, 27, 557.

52. Hesselink, M. B.; Smolders, H.; Eilbacher, B.; De Boer, A. G.; Breimer, D. D.; Danysz, W. J. Pharmacol. Exp. Ther., 1999, 290, 543.

53. Giri, N.; Shaik, N.; Pan, G.; Terasaki, T.; Mukai, C.; Kitagaki, S.; Miyakoshi, N.; Elmquist, W. F. Drug Metab. Dispos., 2008, 36, 1476. 
Table 1 In vitro binding affinity ( $K \mathrm{i})$ of new benzimidazole derivatives for the NR2B subtype of the NMDA receptor and octanol/phosphate buffer distribution coefficient $(\log D)$.

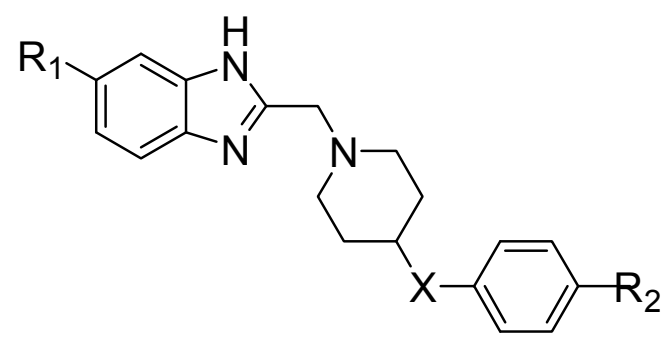

\begin{tabular}{cccccccc}
\hline Compounds & $\mathrm{R}_{1}$ & $\mathrm{R}_{2}$ & $\mathrm{X}$ & $\mathrm{Ki}^{\mathrm{a}}(\mathrm{nM})$ & $\mathrm{Ki}^{\mathrm{b}}(\mathrm{nM})$ & $\log \mathrm{D}_{74}{ }^{\mathrm{c}}$ \\
\hline Ifenprodil & & & & & 20.0 & \pm & 4.89 \\
$\mathbf{1 a}$ & $\mathrm{OH}$ & $\mathrm{H}$ & & 1.50 & 3.09 & \pm 0.22 & \\
$\mathbf{8}$ & $\mathrm{OH}$ & $\mathrm{I}$ & $\mathrm{CH}_{2}$ & & 7.28 & \pm 2.93 & 3.95 \\
$\mathbf{9}$ & $\mathrm{NHSO}_{2} \mathrm{Me}$ & $\mathrm{I}$ & $\mathrm{CH}_{2}$ & & 5.75 & \pm 1.19 & 3.54 \\
$\mathbf{1 3}$ & $\mathrm{OH}$ & $\mathrm{I}$ & $\mathrm{O}$ & & 32.5 & \pm 16.3 & 3.74 \\
\hline
\end{tabular}

${ }^{a}$ Data from Ref. 20. The assay was inhibition study of ${ }^{3} \mathrm{H}-[(E)-N 1-(2-m e t h o x y b e n z y l)$ cinnamamidine] binding to hNR1a/NR2B receptors expressed in Ltk- cells.

${ }^{\mathrm{b}}$ The $K \mathrm{i}$ values were obtained by the method in Ref. 25 . Each value (mean $\pm \mathrm{SD}$ ) was determined triplicate using rat cortical membrane homogenates in HEPES-KOH buffer.

${ }^{c}$ The partition coefficient between n-octanol and sodium phosphate buffer at $\mathrm{pH}=7.4$ $\left(\log D_{7.4}\right)$ was determined by conventional shake-flask method $(\mathrm{n}=3)$. 
Table 2 Effects of drugs on in vitro binding of $\left[{ }^{125}\right.$ I]benzimidazoles to rat brain slices.

\begin{tabular}{|c|c|c|c|c|c|c|}
\hline \multirow[t]{3}{*}{ Ligands } & \multicolumn{6}{|c|}{$\%$ control binding ${ }^{a}$} \\
\hline & \multicolumn{3}{|c|}{$\left.\left[{ }^{125}\right]\right] 8$} & \multicolumn{3}{|c|}{$\left.\left[{ }^{125}\right]\right] 9$} \\
\hline & Cerebral cortex & Hippocampus & Cerebellum & Cerebral cortex & Hippocampus & Cerebellum \\
\hline Ro-25,6981 & 58.3 & 50.9 & 91.8 & 58.1 & 59.0 & 89.3 \\
\hline Prazosin & 95.6 & 92.6 & 102.9 & 92.8 & 95.5 & 97.0 \\
\hline DTG & 93.5 & 104.6 & 101.2 & 93.0 & 107.6 & 103.6 \\
\hline
\end{tabular}

${ }^{a}$ Average values obtained by at least triplicate slices from three rats.

Table 3 Biodistribution data for ${ }^{125}$ I labeled benzimidazoles in normal ddY mice. ${ }^{\text {a }}$

\begin{tabular}{|c|c|c|c|c|c|c|c|c|c|c|c|c|c|c|c|c|c|c|}
\hline \multirow{2}{*}{$\frac{\text { Organ }}{\left[{ }^{125} I\right] \mathbf{8}}$} & \multicolumn{3}{|c|}{$0.5 \mathrm{~min}$} & \multicolumn{3}{|c|}{$5 \mathrm{~min}$} & \multicolumn{3}{|c|}{$30 \mathrm{~min}$} & \multicolumn{3}{|c|}{$60 \mathrm{~min}$} & \multicolumn{3}{|c|}{$180 \mathrm{~min}$} & \multicolumn{3}{|c|}{$360 \mathrm{~min}$} \\
\hline & & & & & & & & & & & & & & & & & & \\
\hline Blood & 3.22 & \pm & 0.58 & 1.15 & \pm & 0.06 & 0.67 & \pm & 0.11 & 0.75 & \pm & 0.13 & 0.30 & \pm & 0.11 & 0.28 & \pm & 0.11 \\
\hline Liver & 14.68 & \pm & 3.50 & 25.03 & \pm & 4.20 & 28.99 & \pm & 6.31 & 30.50 & \pm & 6.60 & 32.22 & \pm & 6.56 & 30.16 & \pm & 1.83 \\
\hline Kidney & 5.35 & \pm & 0.91 & 12.20 & \pm & 3.18 & 11.20 & \pm & 2.65 & 10.34 & \pm & 1.60 & 7.74 & \pm & 1.32 & 5.46 & \pm & 0.67 \\
\hline Intestine & 4.02 & \pm & 0.64 & 1.83 & \pm & 0.33 & 2.39 & \pm & 0.79 & 2.35 & \pm & 0.47 & 4.55 & \pm & 1.03 & 5.89 & \pm & 1.05 \\
\hline Stomach & 0.72 & \pm & 0.16 & 1.93 & \pm & 0.40 & 2.54 & \pm & 0.81 & 2.16 & \pm & 0.24 & 2.51 & \pm & 0.55 & 2.17 & \pm & 0.75 \\
\hline Spleen & 0.50 & \pm & 0.32 & 5.66 & \pm & 1.25 & 5.91 & \pm & 1.25 & 4.65 & \pm & 0.51 & 4.25 & \pm & 0.69 & 3.79 & \pm & 0.43 \\
\hline Pancreas & 0.49 & \pm & 0.13 & 5.74 & \pm & 2.45 & 6.10 & \pm & 1.42 & 6.35 & \pm & 1.25 & 6.53 & \pm & 1.95 & 8.76 & \pm & 0.37 \\
\hline Heart & 1.47 & \pm & 0.29 & 5.39 & \pm & 0.33 & 2.31 & \pm & 0.48 & 1.87 & \pm & 0.41 & 1.58 & \pm & 0.16 & 1.58 & \pm & 0.11 \\
\hline Lung & 6.60 & \pm & 0.95 & 14.48 & \pm & 2.52 & 8.16 & \pm & 2.37 & 7.54 & \pm & 2.19 & 4.75 & \pm & 0.33 & 3.44 & \pm & 0.80 \\
\hline Brain & 0.21 & \pm & 0.03 & 0.42 & \pm & 0.06 & 0.44 & \pm & 0.07 & 0.48 & \pm & 0.09 & 0.56 & \pm & 0.06 & 0.55 & \pm & 0.14 \\
\hline Brain-to-blood ratio & 0.07 & \pm & 0.02 & 0.36 & \pm & 0.03 & 0.67 & \pm & 0.12 & 0.64 & \pm & 0.06 & 1.99 & \pm & 0.57 & 2.23 & \pm & 0.99 \\
\hline \multicolumn{19}{|l|}{$\left.\Gamma^{125} I\right\rceil 9$} \\
\hline Blood & 4.74 & \pm & 1.59 & 0.95 & \pm & 0.40 & 0.53 & \pm & 0.08 & 0.54 & \pm & 0.08 & 0.55 & \pm & 0.12 & 0.36 & \pm & 0.10 \\
\hline Liver & 4.60 & \pm & 2.69 & 19.35 & \pm & 9.22 & 16.67 & \pm & 2.84 & 13.74 & \pm & 1.72 & 17.81 & \pm & 4.07 & 10.93 & \pm & 2.51 \\
\hline Kidney & 3.26 & \pm & 1.64 & 10.99 & \pm & 4.46 & 8.79 & \pm & 0.91 & 8.52 & \pm & 1.98 & 15.23 & \pm & 2.31 & 10.51 & \pm & 1.97 \\
\hline Intestine & 0.55 & \pm & 0.31 & 1.58 & \pm & 0.75 & 3.07 & \pm & 0.50 & 3.79 & \pm & 0.69 & 7.82 & \pm & 1.22 & 6.49 & \pm & 1.77 \\
\hline Stomach & 0.42 & \pm & 0.22 & 1.28 & \pm & 0.47 & 2.24 & \pm & 0.46 & 2.40 & \pm & 1.05 & 4.04 & \pm & 0.83 & 3.56 & \pm & 1.28 \\
\hline Spleen & 0.90 & \pm & 0.61 & 3.19 & \pm & 1.43 & 2.91 & \pm & 0.42 & 2.78 & \pm & 0.57 & 2.85 & \pm & 0.74 & 1.60 & \pm & 0.26 \\
\hline Pancreas & 0.92 & \pm & 0.46 & 3.09 & \pm & 1.59 & 3.71 & \pm & 0.69 & 4.55 & \pm & 1.14 & 5.39 & \pm & 1.18 & 3.72 & \pm & 0.59 \\
\hline Lung & 9.07 & \pm & 5.18 & 5.83 & \pm & 1.29 & 4.29 & \pm & 0.32 & 4.35 & \pm & 0.38 & 6.93 & \pm & 0.36 & 3.62 & \pm & 0.21 \\
\hline Heart & 3.82 & \pm & 1.65 & 3.52 & \pm & 2.19 & 1.86 & \pm & 0.94 & 1.70 & \pm & 0.73 & 1.61 & \pm & 2.29 & 0.93 & \pm & 0.55 \\
\hline Brain & 0.32 & \pm & 0.12 & 0.44 & \pm & 0.19 & 0.50 & \pm & 0.07 & 0.52 & \pm & 0.07 & 0.67 & \pm & 0.08 & 0.47 & \pm & 0.09 \\
\hline Brain to Blood ratio & 0.07 & \pm & 0.01 & 0.46 & \pm & 0.09 & 0.94 & \pm & 0.13 & 1.00 & \pm & 0.26 & 1.23 & \pm & 0.16 & 1.34 & \pm & 0.28 \\
\hline
\end{tabular}

${ }^{\mathrm{a}}\left[{ }^{125} \mathrm{I}\right]$ Benzimidazoles $(14.8 \mathrm{kBq})$ were injected intravenously via tail vein into ddY mice (Male, 6W, 30-35 g). Values were presented as mean \pm S.D. (\%dose/g, $n=5-6$ ). 
Table 4 The modulation of BBB permeability of $\left[{ }^{125} \mathrm{I}\right] \mathbf{8}$ by P-glycoprotein. ${ }^{\text {a }}$

\begin{tabular}{lccccccc}
\hline & \multicolumn{3}{c}{ Control } & \multicolumn{3}{c}{ Cyclosporin A $(50 \mathrm{mg} / \mathrm{kg})$} \\
\hline Blood & 0.78 & \pm & 0.27 & & 0.52 & \pm & 0.26 \\
Liver & 16.20 & \pm & 1.34 & & 15.20 & \pm & 5.71 \\
Kidney & 4.49 & \pm & 1.34 & & 4.80 & \pm & 0.69 \\
Brain & 0.50 & \pm & 0.04 & & 0.66 & \pm & 0.22 \\
& & & & & & & \\
Brain/blood & 0.74 & \pm & 0.41 & & 1.16 & \pm & 0.36 \\
\hline
\end{tabular}

${ }^{\text {a }}$ Regional organ uptake at $180 \mathrm{~min}$ after $\left[{ }^{125} \mathrm{I}\right] \mathbf{8}$ injection. Cyclosporin A (50 mg/kg) was given as pre-treatment by intravenous injection $30 \mathrm{~min}$ before $\left[{ }^{125} \mathrm{I}\right] \mathbf{8}(148 \mathrm{kBq})$ administration. Values were presented as mean \pm S.D. $(\%$ dose $/ g, n=5)$.

Table 5 The modulation of BBB permeability of $\left[{ }^{125} \mathrm{I}\right] \mathbf{8}$ by organic anion transporter. ${ }^{\mathrm{a}}$

\begin{tabular}{|c|c|c|c|c|c|c|c|}
\hline & & ont & & Probene & $\mathrm{d}(2$ & $\mathrm{mg} / \mathrm{kg}$ & \\
\hline Blood & 0.46 & \pm & 0.07 & 0.41 & \pm & 0.11 & \\
\hline Brain & 0.44 & \pm & 0.06 & 0.57 & \pm & 0.19 & \\
\hline Liver & 19.13 & \pm & 2.09 & 20.03 & \pm & 5.81 & \\
\hline Kidney & 6.29 & \pm & 1.47 & 4.20 & \pm & 0.97 & \\
\hline Brain/Blood & 0.98 & \pm & 0.13 & 1.43 & \pm & 0.37 & \\
\hline
\end{tabular}

${ }^{a}$ Regional organ uptake at $180 \mathrm{~min}$ after $\left[{ }^{125} \mathrm{I}\right] \mathbf{8}$ injection. Probenecid $(200 \mathrm{mg} / \mathrm{kg})$ was given as pre-treatment by intravenous injection $30 \mathrm{~min}$ before $\left[{ }^{125} \mathrm{I}\right] \mathbf{8}(148 \mathrm{kBq})$ administration.

Values were presented as mean \pm S.D. (\%dose $/ g, n=5) .{ }^{*} \mathrm{P}<0.05$ in comparison to the control group (Mann-Whitney U-test). 


\section{Legends.}

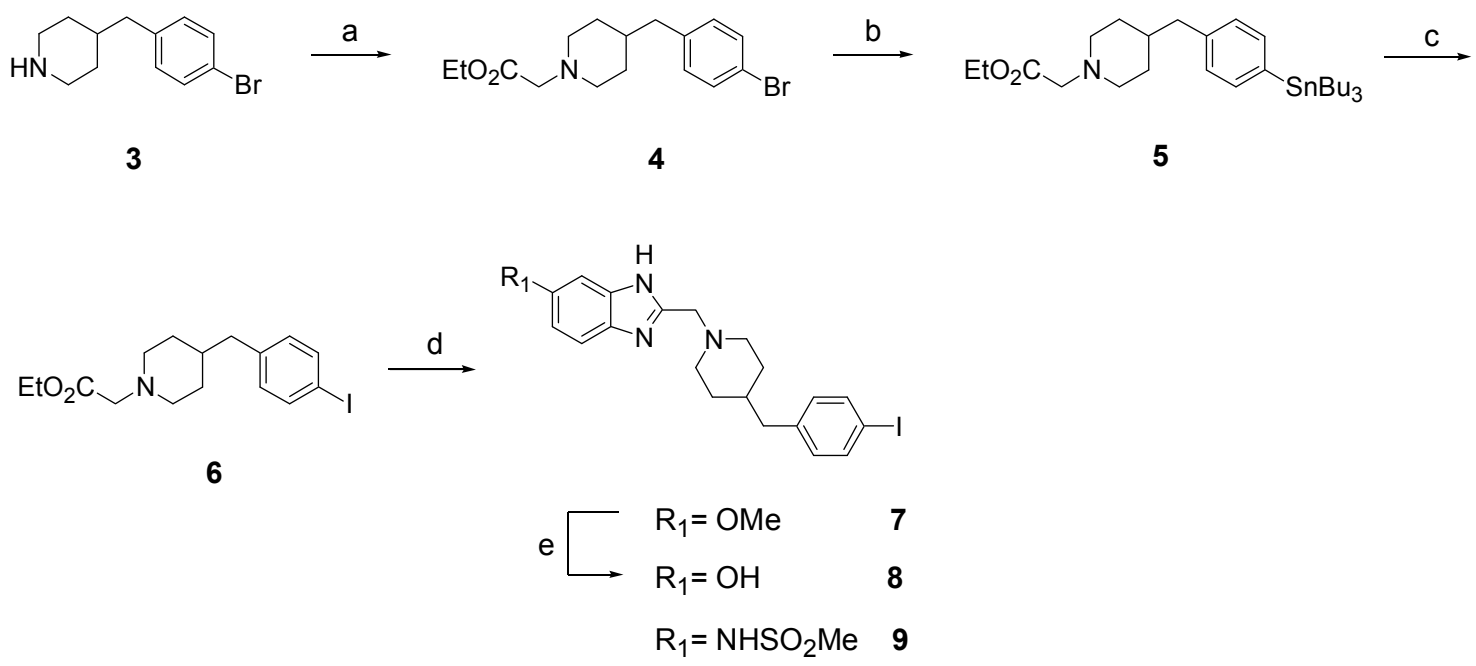

Scheme 1. Preparation of benzylpiperidine derivatives (8 and $\mathbf{9})$.

Reagent and conditions: (a) ethyl bromoacetate, diisopropylethylamine, DMF, r.t., 71 \%; (b) $\left(\mathrm{Bu}_{3} \mathrm{Sn}\right)_{2},\left(\mathrm{Ph}_{3} \mathrm{P}\right)_{4} \mathrm{Pd}$, toluene, $110{ }^{\circ} \mathrm{C}, 53 \%$; (c) $\mathrm{I}_{2}, \mathrm{CCl}_{4}$, r.t., $68 \%$; (d) 1) HCl, 100 ${ }^{\circ} \mathrm{C}$, 2) EDC, HOAt, triethylamine, 4-substituted phenylenediamine, DMF, r.t., 3) acetic acid, $140{ }^{\circ} \mathrm{C}, 55 \%$ for $7,53 \%$ for 9 ; (e) $\mathrm{HBr} / \mathrm{H}_{2} \mathrm{O}, 100{ }^{\circ} \mathrm{C}, 63 \%$.

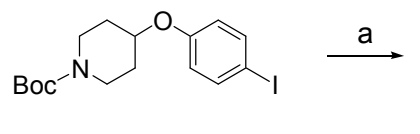

10

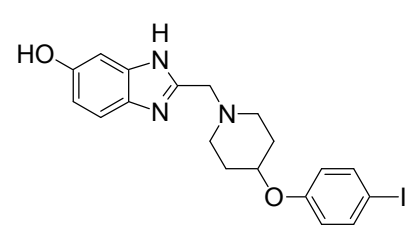

13

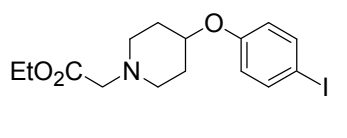

11

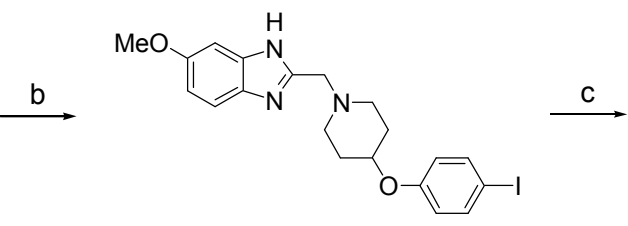

12

Scheme 2. Preparation of phenoxypiperidine derivative (13).

Reagent and conditions: (a) 1) TFA, $\mathrm{CH}_{2} \mathrm{Cl}_{2}$, r.t., 2) ethyl bromoacetate, diisopropylethylamine, DMF, r.t., $45 \%$; (b) 1) $\mathrm{HCl}, 100{ }^{\circ} \mathrm{C}$, 2) EDC, HOAt, triethylamine, 4-substituted phenylenediamine, DMF, r.t., 3) acetic acid, $140{ }^{\circ} \mathrm{C}, 73 \%$; (c) $\mathrm{BBr}_{3}, \mathrm{CH}_{2} \mathrm{Cl}_{2}$, r.t., $77 \%$. 


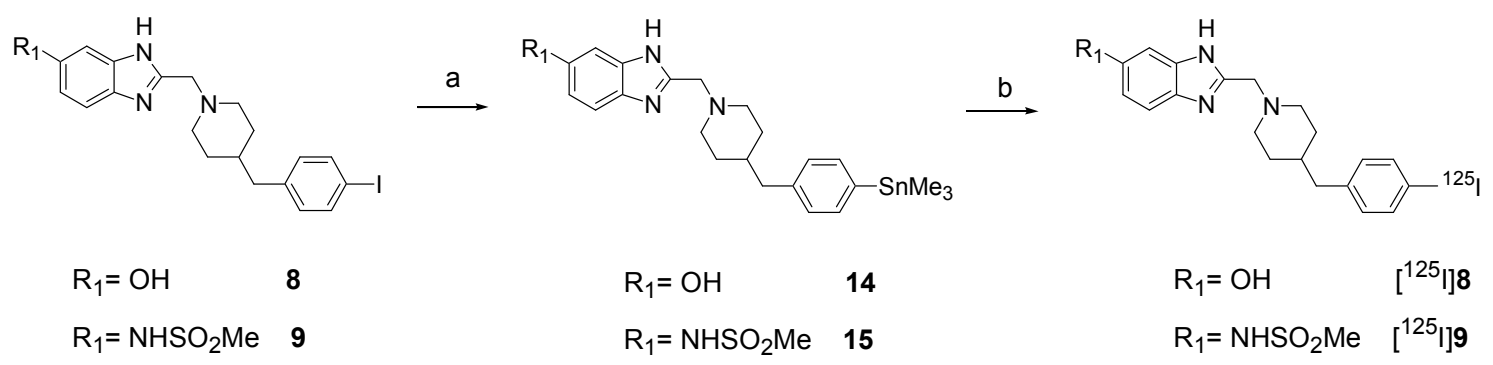

Scheme 3. Preparation of $\left[{ }^{125} \mathrm{I}\right] \mathbf{8}$ and $\left[{ }^{125} \mathrm{I}\right] \mathbf{9}$.

Reagent and conditions: (a) $\left(\mathrm{Me}_{3} \mathrm{Sn}\right)_{2},\left(\mathrm{Ph}_{3} \mathrm{P}\right)_{4} \mathrm{Pd}$, toluene, $110{ }^{\circ} \mathrm{C}, 53 \%$ for 14 and $97 \%$ for 15; (b) $\left[{ }^{125} \mathrm{I}\right] \mathrm{NaI}, \mathrm{H}_{2} \mathrm{O}_{2}, \mathrm{HCl}$, EtOH, r.t., $85-90 \%$ for $\left[{ }^{125} \mathrm{I}\right] \mathbf{8}$ and $78-81 \%$ for $\left[{ }^{125} \mathrm{I}\right] \mathbf{9}$.

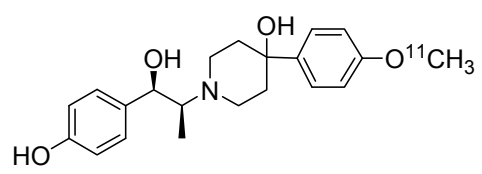

$\left[{ }^{11} \mathrm{C}\right] \mathrm{CP}-101,606$ derivative<smiles>COc1ccccc1CNC(=N)/C=C/c1ccccc1</smiles>

$\left[{ }^{11} \mathrm{C}\right]$ Benzylamidine derivative

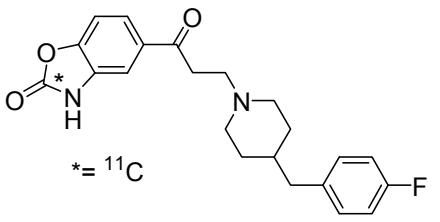

$\left[{ }^{11} \mathrm{C}\right]$ EMD-95885

Figure 1. Structure of radioligands for imaging of the NR2B subtype of the NMDA receptor

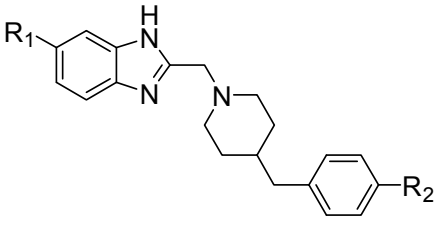

1

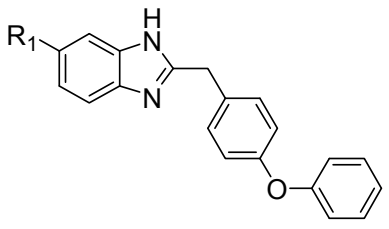

2

1a; $\mathrm{R}_{1}=\mathrm{OH}, \mathrm{R}_{2}=\mathrm{H}$

$$
\begin{aligned}
& \mathrm{R}_{1}=\mathrm{OH}, \mathrm{NHSO}_{2} \mathrm{Me} \\
& \mathrm{R}_{2}=\mathrm{Me}, \mathrm{F}, \mathrm{Cl}
\end{aligned}
$$

Figure 2. Structure of benzimidazoles as NR2B antagonists 
A

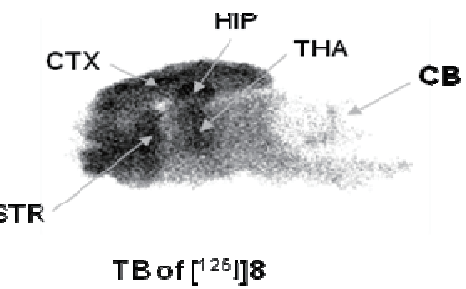

B

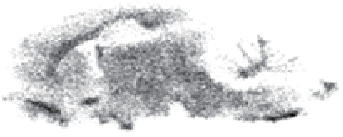

NSB of ${ }^{[25}[] 8$

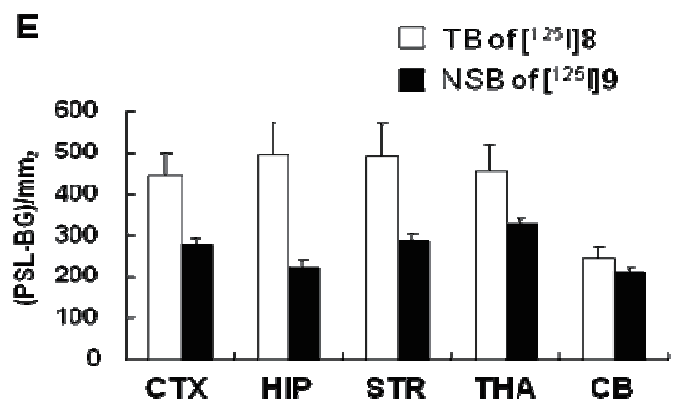

C

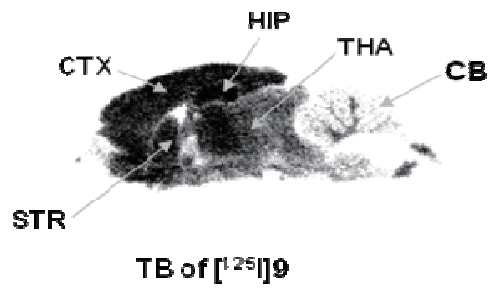

D

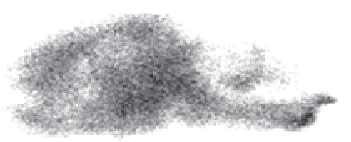

NSB of [125] $] 9$

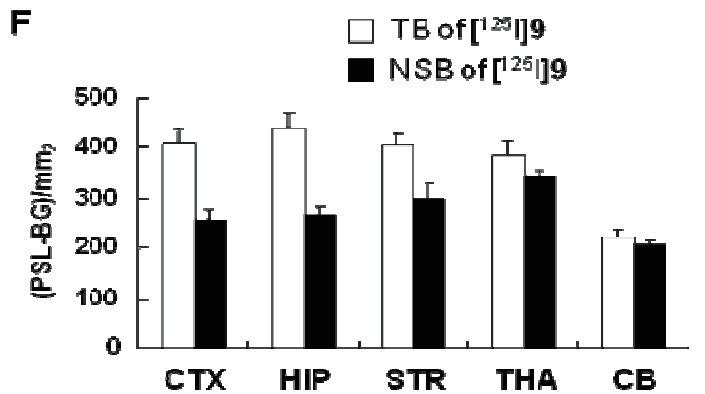

Figure 3. Autoradiogram of in vitro total binding (TB) of $\left[{ }^{125} \mathrm{I}\right] \mathbf{8}(\mathrm{A})$, nonspecific binding (NBS) of $\left[{ }^{125} \mathrm{I}\right] \mathbf{8}(\mathrm{B})$, total binding of $\left[{ }^{125} \mathrm{I}\right] \mathbf{9}(\mathrm{C})$, and nonspecific binding of $\left[{ }^{125} \mathrm{I}\right] \mathbf{9}$ (D) to rat brain sagittal sections. The quantified values of $\left[{ }^{125} \mathrm{I}\right] \mathbf{8}(\mathrm{E})$ and $\left[{ }^{125} \mathrm{I}\right] \mathbf{9}$ (F) in the cerebral cortex, hippocampus, and cerebellum were expressed as $(\mathrm{PSL}-\mathrm{BG}) / \mathrm{mm}_{2}($ mean $\pm \mathrm{SD}, \mathrm{n}=4-6)$. Nonspecific binding was determined in the presence of corresponding nonradioactive benzimidazoles $(10 \mu \mathrm{M})$.

$* \mathrm{P}<0.01$ in comparison to the control group (Mann-Whitney U-test). 
$\square$ min $\square 30 \mathrm{~min} \square 60 \mathrm{~min} \square 180 \mathrm{~min} \times 360 \mathrm{~min}$

(A)

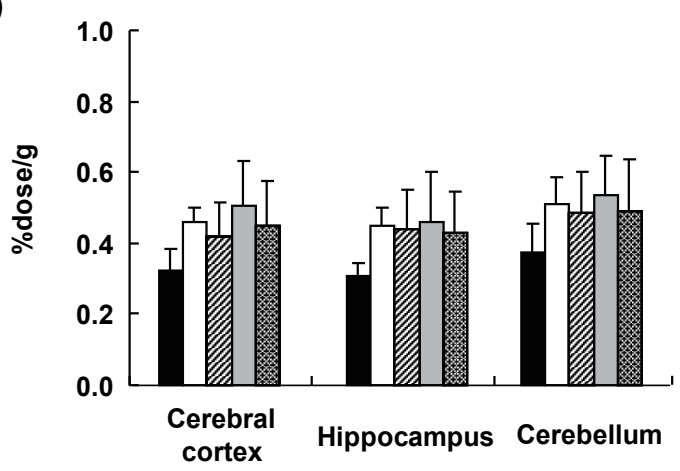

(B)

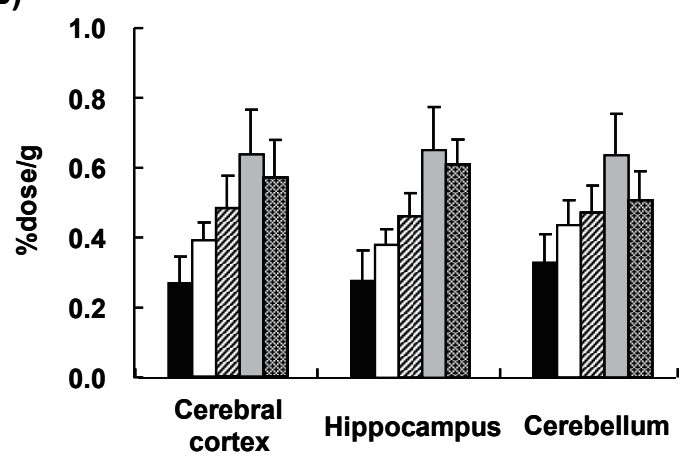

Figure 4. Regional brain uptake of $\left[{ }^{125} \mathrm{I}\right] \mathbf{8}$ (A) and $\left[{ }^{125} \mathrm{I}\right] \mathbf{9}$ (B) in normal ddY mice. $\left[{ }^{125} \mathrm{I}\right]$ Benzimidazoles $(148 \mathrm{kBq})$ were injected intravenously via mice tail vein. 
Control $\square 8 \square$ Ro,25,6981

(A)

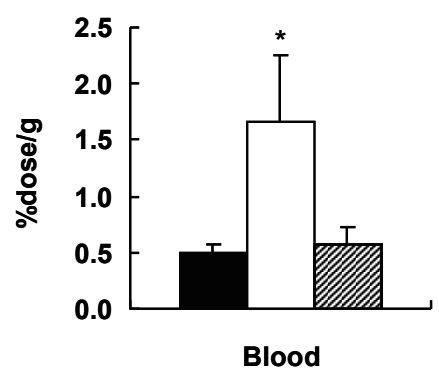

(C)

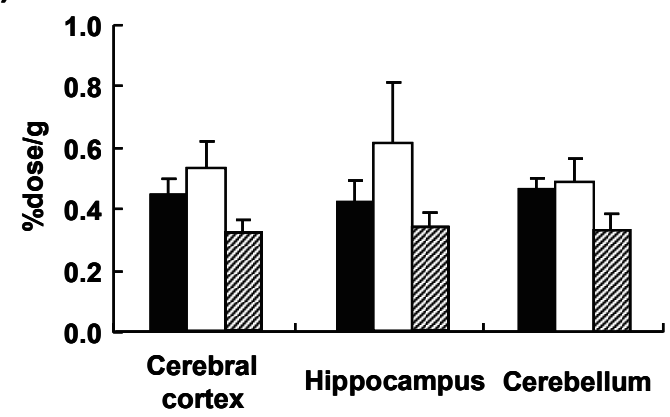

(B)

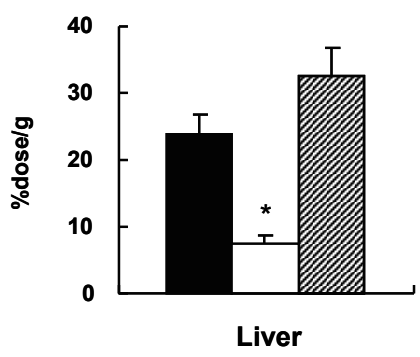

(D)

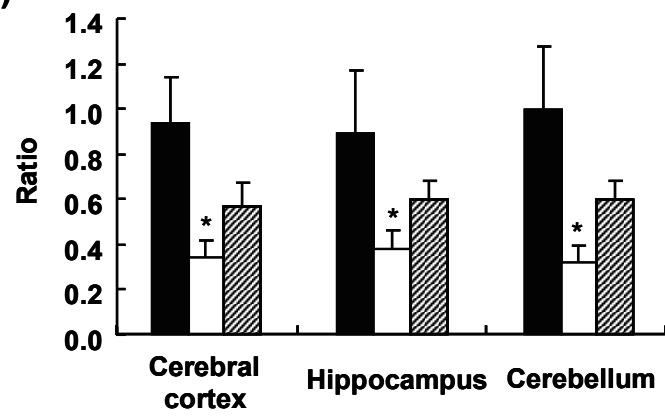

Figure 5. Effects of non-radioactive 8 and Ro-25,6981 (NR2B antagonist) on the blood concentration (A), liver uptake (B), regional brain uptake (C), and brain tissue to blood ratio (D) of $\left[{ }^{125} \mathrm{I}\right] \mathbf{8}$ in mice at $180 \mathrm{~min}$ after injection. Drugs $(3 \mathrm{mg} / \mathrm{kg})$ were given as pre-treatment by intravenous injection $30 \mathrm{~min}$ before $\left[{ }^{125} \mathrm{I}\right] \mathbf{8}(148 \mathrm{kBq})$ administration. Values were presented as mean \pm S.D. (\%dose/g, $n=5)$. ${ }^{*} \mathrm{P}<0.01$ in comparison to the control group (Kruskal-Wallis test, post test was Dunn's test). 